\title{
A Smart and Sustainable Future for Viticulture Is Rooted in Soil: How to Face Cu Toxicity
}

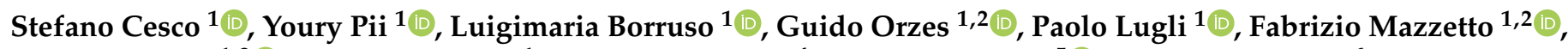 \\ Giulio Genova ${ }^{1,3}{ }^{(}$, Marco Signorini ${ }^{1}$, Gustavo Brunetto ${ }^{4}$, Roberto Terzano ${ }^{5}{ }^{\circ}$, Gianpiero Vigani ${ }^{6}$ \\ and Tanja Mimmo 1,2,*(D)
}

Citation: Cesco, S.; Pii, Y.; Borruso, L.; Orzes, G.; Lugli, P.; Mazzetto, F.; Genova, G.; Signorini, M.; Brunetto, G.; Terzano, R.; et al. A Smart and Sustainable Future for Viticulture Is Rooted in Soil: How to Face $\mathrm{Cu}$ Toxicity. Appl. Sci. 2021, 11, 907. https://doi.org/10.3390/app11030907

Received: 18 November 2020

Accepted: 13 January 2021

Published: 20 January 2021

Publisher's Note: MDPI stays neutral with regard to jurisdictional claims in published maps and institutional affiliations.

Copyright: (c) 2021 by the authors. Licensee MDPI, Basel, Switzerland. This article is an open access article distributed under the terms and conditions of the Creative Commons Attribution (CC BY) license (https:// creativecommons.org/licenses/by/ $4.0 /)$.
1 Faculty of Science and Technology, Free University of Bozen-Bolzano, Piazza Università 5, 39100 Bolzano, Italy; stefano.cesco@unibz.it (S.C.); youry.pii@unibz.it (Y.P.); luigimaria.borruso@unibz.it (L.B.); guido.orzes@unibz.it (G.O.); paolo.lugli@unibz.it (P.L.); fabrizio.mazzetto@unibz.it (F.M.); giulio.genova@natec.unibz.it (G.G.); marco.signorini@natec.unibz.it (M.S.)

2 Competence Centre for Plant Health, Free University of Bozen-Bolzano, 39100 Bolzano, Italy

3 Eurac Research, Institute for Alpine Environment, 39100 Bolzano, Italy

4 Department of Soil Science, Universidade Federal de Santa Maria, Av.Roraima, 1000, Camobi, Santa Maria, RS 97105-900, Brazil; brunetto.gustavo@gmail.com

5 Department of Soil, Plant and Food Sciences, University of Bari "Aldo Moro", 70126 Bari, Italy; roberto.terzano@uniba.it

6 Department of Life Science and System Biology, University of Torino-Turin, 10124 Torino, Italy; gianpiero.vigani@unito.it

* Correspondence: tanja.mimmo@unibz.it

Abstract: In recent decades, agriculture has faced the fundamental challenge of needing to increase food production and quality in order to meet the requirements of a growing global population. Similarly, viticulture has also been undergoing change. Several countries are reducing their vineyard areas, and several others are increasing them. In addition, viticulture is moving towards higher altitudes and latitudes due to climate change. Furthermore, global warming is also exacerbating the incidence of fungal diseases in vineyards, forcing farmers to apply agrochemicals to preserve production yields and quality. The repeated application of copper $(\mathrm{Cu})$-based fungicides in conventional and organic farming has caused a stepwise accumulation of $\mathrm{Cu}$ in vineyard soils, posing environmental and toxicological threats. High $\mathrm{Cu}$ concentrations in soils can have multiple impacts on agricultural systems. In fact, it can (i) alter the chemical-physical properties of soils, thus compromising their fertility; (ii) induce toxicity phenomena in plants, producing detrimental effects on growth and productivity; and (iii) affect the microbial biodiversity of soils, thereby influencing some microbial-driven soil processes. However, several indirect (e.g., management of rhizosphere processes through intercropping and/or fertilization strategies) and direct (e.g., exploitation of vine resistant genotypes) strategies have been proposed to restrain $\mathrm{Cu}$ accumulation in soils. Furthermore, the application of precision and smart viticulture paradigms and their related technologies could allow a timely, localized and balanced distribution of agrochemicals to achieve the required goals. The present review highlights the necessity of applying multidisciplinary approaches to meet the requisites of sustainability demanded of modern viticulture.

Keywords: copper; rhizosphere; smart agriculture; microbes; vineyard

\section{Introduction}

In recent decades, the food demand has significantly increased in terms of quality and quantity due to the increase in the global population, which has now reached almost 8 billion people [1]. The growth of the per capita income in developing countries has undoubtedly played a decisive role [2,3]. On the other hand, the arable soil surface has decreased due to soil degradation and the impact of climate change [4]. Indeed, 
we are experiencing a global annual mean warming of $1{ }^{\circ} \mathrm{C}$ above the level of the preindustrialization period [5]. Moreover, the global non-renewable natural resources used for the production of fertilizers (e.g., rock phosphate) are limited and are expected to be consumed shortly [6]. All these trends highlight the limits and the vulnerability of the current model of economic and social growth based on mass production and consumption, including with respect to soil [7].

For this reason, the United Nations defined 17 Sustainable Development Goals (SDGs) and 169 target actions for the year 2030, to which we are all invited to proactively contribute. These include targets of no poverty, zero hunger, good health and well-being, life below water, life on land, and climate action. In this context, agriculture is called upon to contribute by providing primary production and to reduce its anthropogenic impacts on the environment.

A specific example is represented by copper $(\mathrm{Cu})$ accumulation in agricultural soils due to the massive application of metal-contaminated sludges and/or Cu-based pesticides for crop defense plans against pathogens. While $\mathrm{Cu}$ is an essential micronutrient for equilibrated crop growth, excessive $\mathrm{Cu}$ concentration, due to its accumulation in soil, leads to severe symptoms of toxicity, which are beginning to be recognized in crops, particularly in acid soils $[8,9]$. The case of vineyard soils is the most emblematic. Therefore, specific strategies must be adopted to limit and/or mitigate this problem, particularly in the viticulture sector.

This review aims at shedding light on the soil vineyard $\mathrm{Cu}$ accumulation and its agricultural and environmental consequences, specifically at the European level. Some approaches to limiting $\mathrm{Cu}$ toxicity and the related challenges, considering recent technological innovations (rhizosphere management, biotechnologies and precision/smart viticulture), are discussed. A short description of the role of $\mathrm{Cu}$ as an essential nutrient for plants is also included. The review further highlights research gaps that urgently require further study and innovation in order to guarantee sustainable vineyard management, providing soil conditions that will enable quality viticulture in the long term.

\subsection{Cu in Agricultural Soils and Crops}

Copper is a trace element in soil-plant systems. The average $\mathrm{Cu}$ concentration in the Earth's crust is $60 \mathrm{mg} \mathrm{kg}^{-1}$ and in soil, it typically ranges between 2 and $50 \mathrm{mg} \mathrm{kg}^{-1}$. Natural soils with a high content of clay minerals (e.g., Vertisols) or organic matter (e.g., Spodosols, Histosols) are usually characterized by a higher $\mathrm{Cu}$ content (up to $180 \mathrm{mg} \mathrm{kg}^{-1}$ ) [10]. Anthropogenic atmospheric depositions (traffic and industry related) and agricultural materials (inorganic fertilizers, agrochemicals, sewage sludge, livestock manure, irrigation water, compost, etc.) can dramatically increase the $\mathrm{Cu}$ concentration in soil. Indeed, $\mathrm{Cu}$ concentrations higher than $1000 \mathrm{mg} \mathrm{kg}^{-1}$ have been recorded in polluted soils, including in agricultural soils [11]. In particular, concentrations exceeding $1000 \mathrm{mg} \mathrm{kg}^{-1}$ have been reported for vineyard soils in France and Brazil [9] (see also the following chapter).

The main form of $\mathrm{Cu}$ in the soil is $\mathrm{Cu}^{2+}$, typically bound to inorganic and organic ligands, forming both soluble and insoluble compounds. In the solid phase, $\mathrm{Cu}$ has a very high affinity for organic matter and manganese oxides, as well as for iron oxides and clay minerals. Because of its high affinity for soil colloids and especially organic matter, $\mathrm{Cu}$ shows low mobility in near-neutral soils and is mainly concentrated in the upper soil layers. For instance, in rhizosphere soil (i.e., at the root-soil-microorganism interface), $\mathrm{Cu}$ is complexed by low-molecular-weight organic compounds exuded by plants and microbes like carboxylic and phenolic acids, which play an essential role in both external and internal plant tolerance mechanisms [9]. In arable soils, $\mathrm{Cu}$ concentration in the soil solution lies in the range 1-300 $\mu \mathrm{g} \mathrm{L}^{-1}$ [12].

Concerning the plant acquisition process, roots can use the free ionic forms $\left(\mathrm{Cu}^{+} / \mathrm{Cu}^{2+}\right)$, although the direct use of $\mathrm{Cu}$ complexes with different organic molecules present in the rhizosphere cannot be excluded. Indeed, the identification of an uptake system of Fephytosiderophore (i.e., root exudates with a high affinity for $\mathrm{Fe}$ ) complexes also in di- 
cots [13] further corroborates this hypothesis. Moreover, a reduction step $\left(\mathrm{Cu}^{2+} \rightarrow \mathrm{Cu}^{+}\right)$ is also very likely to occur before the root uptake of the nutrient [9]. Indeed, previous works demonstrated that Fe chelate reductase enzymes and their related gene family $(F R O)$ responded to both $\mathrm{Cu}$ deficiency and toxicity in Arabidopsis thaliana and cucumber plants, respectively $[14,15]$. The metal is taken up through a specific transmembrane $\mathrm{Cu}$ Transporter Protein 1 (COPT1) [16]. However, the involvement of other transporters like $\mathrm{Zn} / \mathrm{Fe}$ Permeases (ZIPs), Natural Resistance Associated Macrophage Proteins (NRAMP) and Iron Related Transporters (IRT) has also been speculated [17-20]. In this context, the extent of the $\mathrm{Cu}$ bioavailable fraction (i.e., the two free ionic $\mathrm{Cu}$ forms and the soluble metal complexes with organic ligands) strongly depends on soil properties, especially cation exchange capacity (CEC), $\mathrm{pH}$ values, organic matter and clay content [12].

Once taken up by the roots, $\mathrm{Cu}$ is loaded into the xylem vessels to be translocated towards the aboveground organs. Despite only a few pieces of information available, the Heavy Metal-transporting P-type ATPase 5 (OsHMA5) has been shown to be involved in the $\mathrm{Cu}$ xylem-loading in rice plants [21]. In this respect, the $\mathrm{Cu}$ concentration in the xylem sap and in shoots is remarkably limited when the expression of this gene is down-regulated. Moreover, in A. thaliana, Yellow Stripe Like 2 (YSL2) transporter was also found to play a pivotal role in the xylem loading of $\mathrm{Cu}$ complexed with nicotianamine [22]. Once loaded in the xylem, $\mathrm{Cu}$ is bound to an organic ligand, generally amino acids (like histidine and proline in Brassica carinata) or nicotianamine (e.g., in tomato and chicory) [23-25]. Once at the leaf level, before being taken up by the cells, the $\mathrm{Cu}^{2+}$ complexes need to be reduced to $\mathrm{Cu}^{+}$by FRO4 [26] and, only after its transmembrane transport, the metal is delivered to the different organelles (e.g., mitochondria and chloroplasts) through specific transporters [27].

In plant cells, $\mathrm{Cu}$ is involved in a plethora of biochemical and physiological processes, including photosynthesis, respiration, oxidative stress responses, cell wall metabolism, and hormone signaling $[28,29]$. In fact, $\mathrm{Cu}$ is an important cofactor in many proteins, such as plastocyanin, cytochrome c-oxidase and amino oxidase [28]. Generally, the $\mathrm{Cu}$ concentrations in plant tissues growing in uncontaminated soils range from 5 to $30 \mathrm{mg} \mathrm{kg}^{-1}$ dry weight, depending on the type of plant, the growth stage, and the soil characteristics. Deficiency symptoms can appear at $\mathrm{Cu}$ concentrations lower than $5 \mathrm{mg} \mathrm{kg}^{-1} \mathrm{dry}$ weight, while leaf concentration higher than $20 \mathrm{mg} \mathrm{kg}^{-1}$ dry weight may result in toxic effects affecting the whole plant development [30-32].

\subsection{Current Situation in Vineyards (Including Toxicity in Plants and Effects)}

Several studies have reported an accumulation of metals in agricultural soils due to common agricultural practices, such as manure fertilization and spraying for pest control [33-35]. For instance, $\mathrm{Cu}$ in apple orchards can have an average annual total increase ranging from 2.5 to $9 \mathrm{mg} \mathrm{kg}^{-1}$ year ${ }^{-1}$ deriving from the application of $\mathrm{Cu}$-containing agrochemicals [36]. The accumulation of $\mathrm{Cu}$ through time can be influenced not only by the age, but also by other factors, such as soil organic matter content and $\mathrm{pH}$ [33]. As shown in Figure 1, vineyard soils are prone to $\mathrm{Cu}$ accumulation, since the practice of spraying $\mathrm{Cu}$ salts as fungicides dates back at least as far as 1761 [37]. After the introduction in 1885 of the mixture of Cu sulfate and lime, called "Bordeaux mixture" [38], its use became generalized on wine-producing farms. Because of this, the concentration of $\mathrm{Cu}$ in vineyards can be many times higher than the background values of forest soils in the same region, reaching up to $3000 \mathrm{mg} \mathrm{kg}^{-1}[39,40]$. Next, high $\mathrm{Cu}$ concentration differences can also be found inter-row and intra-row within the same vineyard [41]. 


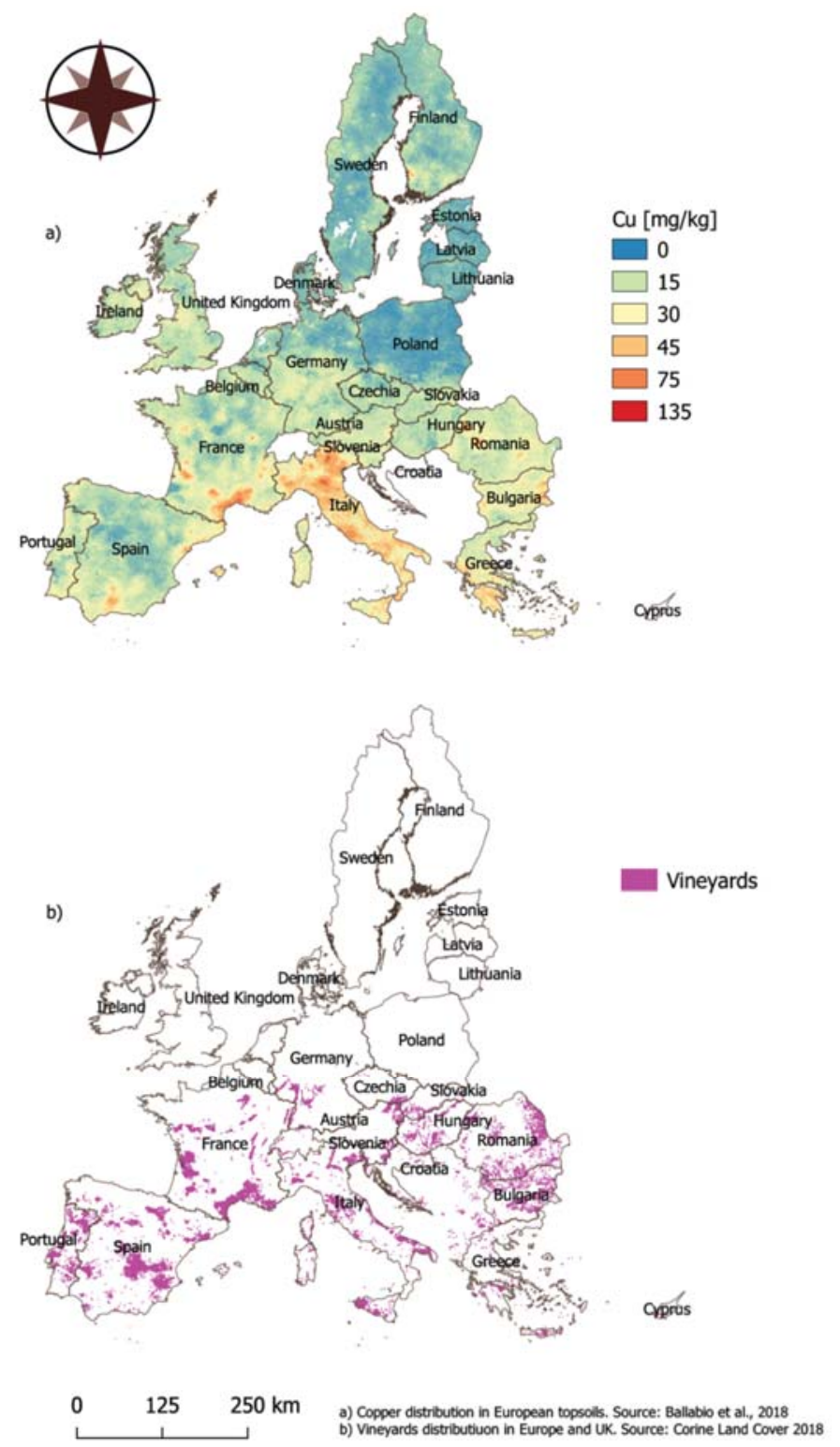

Figure 1. Cu concentration distribution (a) compared to the distribution of vineyards (b) in Europe [42]. Several high $\mathrm{Cu}$ concentration areas perfectly match viticulture areas.

Although much research is currently taking place to find alternatives to $\mathrm{Cu}$, this element is still crucial to fighting fungal diseases in vines, especially in organic farming, limiting the supply of pure $\mathrm{Cu}$ to $28 \mathrm{~kg} \mathrm{ha}^{-1}$ over a period of 7 years [43-45]. For these reasons, the global trends of vine-cultivated areas and the use of $\mathrm{Cu}$ should be monitored, particularly in newly planted vineyards. Indeed, the shallow root system of newly planted vine plants might be more affected by high $\mathrm{Cu}$ levels than older plants, since Cu mainly accumulates in the upper soil layers (where the concentration of organic matter is higher). In fact, the first effects of $\mathrm{Cu}$ phytotoxicity are evident at the root level, with a clear decrease of root elongation, abnormal root branching, thickening and dark coloration [46]. As a consequence of this altered root development, the roots' ability to take up water and other nutrients is clearly impaired [32,47]. In this regard, it is worth mention the negative effect of $\mathrm{Cu}$ toxicity on $\mathrm{P}$ acquisition by roots [48,49], highlighting the interactions occurring between the different nutrient acquisition mechanisms. Critical $\mathrm{Cu}$ concentrations in roots range from 100 to $400 \mathrm{mg} \mathrm{kg}^{-1}$ dry weight $[10,46]$. Like other heavy metals, an excess of $\mathrm{Cu}$ may also cause the generation of toxic reactive oxygen species (ROS), which, in turn, can damage several important biomolecules like DNA, proteins and lipids [50]. Usually, 
plants exhibit an excellent translocation barrier of excessive $\mathrm{Cu}$ between roots and shoots. This limits the risk of $\mathrm{Cu}$ accumulation in edible plant tissues that exceeds toxic levels to livestock and humans. However, toxic concentration levels, as well as symptoms of $\mathrm{Cu}$ toxicity, have also been well described for the aerial part of plants [30-32]. Typical cases of $\mathrm{Cu}$ toxicity at the root and shoot levels of vine plants (Vitis vinifera L., cv Glera) are presented in Figure 2.

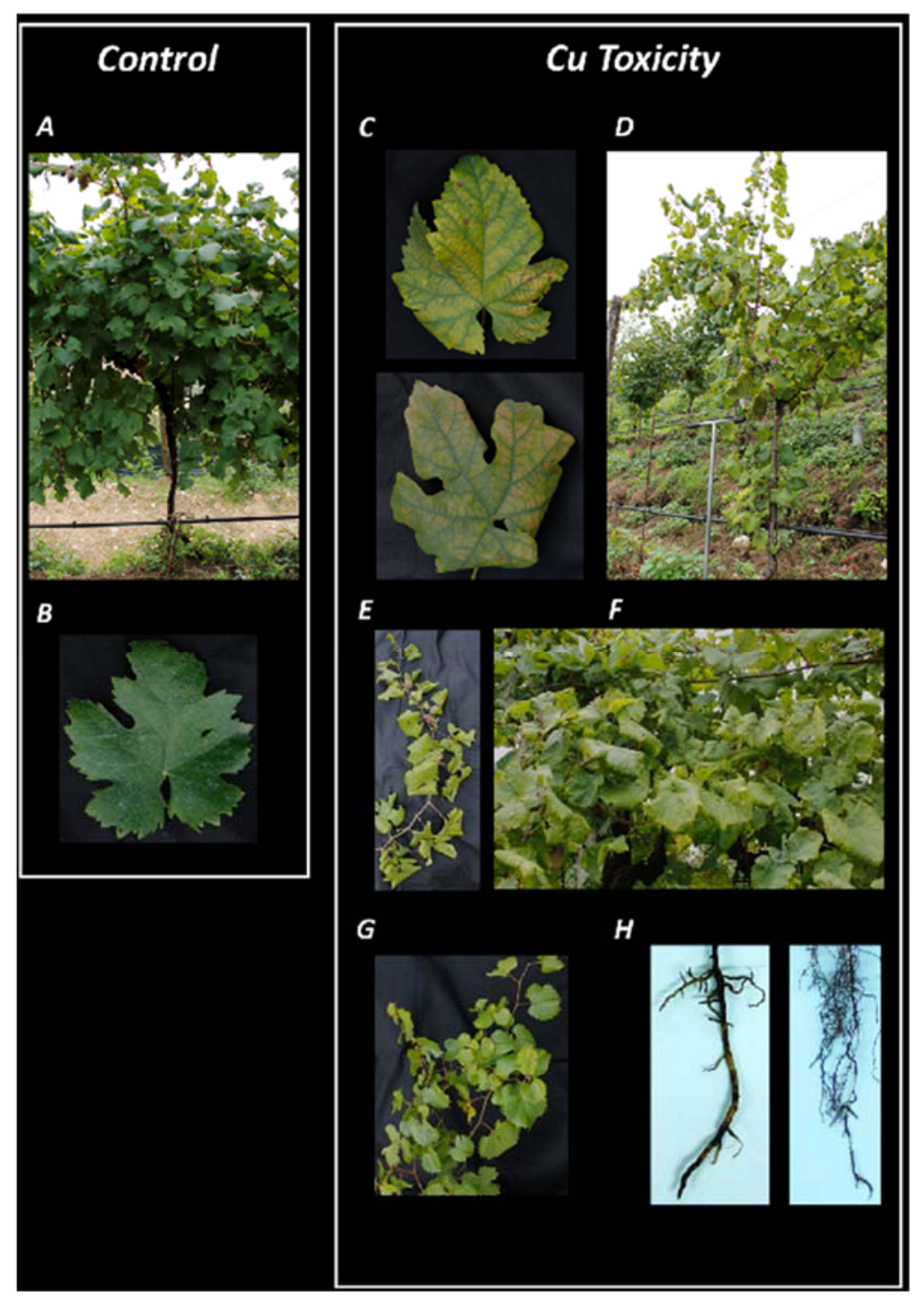

Figure 2. Symptoms of $\mathrm{Cu}$ toxicity in vine plants grown in a soil with $814 \mathrm{mg} \mathrm{kg}^{-1} \mathrm{Cu}$ (DTPA extractable fraction: $280 \mathrm{mg} \mathrm{kg}^{-1} \mathbf{C u}$ ): (D-F) canopy, (C) leaves and (H) roots of grafted plants of Vitis vinifera L. (cv. Glera); (G) canopy of the rootstock SO4 (V. berlandieri $x$ V. riparia). As control, canopy (A) and leaf (B) of healthy vine plants (Vitis vinifera L. cv Glera).

Considering the soil surface dedicated to viticulture, in 2019, worldwide vine cultivation covered 7.4 million hectares [51], and it has been considered stable in recent years, with a global balance given by heterogeneous evolution in different regions of the world [52]. In Europe (Figure 1), the vine-cultivated area is stable, being balanced between the European Union "grubbing up" program (i.e., the replacement of vine plants with other agricultural crops, [53]) on the one hand, and the possibility of Member States authorizing the planting of up to $1 \%$ of the vineyard surface already planted each year [54], on the other hand. Globally, several countries are increasing their vineyard area, namely Russia, New Zealand, Peru, and China, to name a few. Meanwhile, countries like USA, Argentina, 
Chile are showing a decline in vineyard area [51]. In addition to wine regulations and the global market [55], Climate Change is playing a fundamental role in directing the spatial distribution of vines, as increasing temperatures are leading to vineyards higher in elevation and at higher latitudes [56,57]. Climate change also affects the incidence of fungal infections in vineyards, requiring increasing use of $\mathrm{Cu}$-based treatments [9]. These changes will then affect the chemical and biological quality of soils of newly planted vines with increasingly higher $\mathrm{Cu}$ concentrations. In this regard, it is interesting to note that the annual supply of $\mathrm{Cu}$ for pathogen defense plans can range from $1-2 \mathrm{~kg} \mathrm{ha}^{-1}$ in Europe to $30 \mathrm{~kg} \mathrm{ha}^{-1}$ in southern Brazil [58] as a function of the infectious pressure of the pathogens. Furthermore, new crops growing where there used to be vineyards might be affected by high $\mathrm{Cu}$ concentrations and exhibit symptoms of toxicity.

European countries have different approaches to defining threshold levels, as there is large heterogeneity in the legal systems, the chemical analysis used, the target organisms for toxicity, and background-values and how these are defined. In addition, other soil properties (mainly $\mathrm{pH}$ and $\mathrm{SOM}$ ) and the precipitations/humidity of wine areas can be used as additional data to determine the final threshold level since the need for applying higher quantities of active principle can influence the decision-taking process [59-61]. In Italy, for instance, the management of polluted sites is regulated by the law D. Lgs. $152 / 2006$, and a recent Decree established $200 \mathrm{mg} \mathrm{kg}^{-1}$ of $\mathrm{Cu}$ as the contamination limit for agricultural soils [62]. A literature review showed a high degree of heterogeneity and a lack of standard approaches and thresholds for heavy metal risk assessment [59]. For example, the Austrian standard ON S 2088-2 defines a two-step evaluation in which, firstly, soil metal content is measured $\left(\mathrm{NH}_{4} \mathrm{NO}_{3}\right.$-extract). If certain trigger values are reached, then the possible bioavailability is evaluated in consideration of the metal content and other soil parameters, such as $\mathrm{pH}$ and soil organic matter, thus resulting in a final contamination evaluation [59]. The Czech Republic provides indication limits on plant growth inhibition [63] in consideration of the metal content extracted with aqua regia $\left(\mathrm{HCl}\right.$ and $\mathrm{HNO}_{3}$ at a ratio of 3:1) or with $1 \mathrm{~mol} \mathrm{~L}^{-1}$ of $\mathrm{NH}_{4} \mathrm{NO}_{3}$. Both extractions must be performed if the limit values for the specific metal are defined. At the global level, the lack of a standardized approach on $\mathrm{Cu}$ content thresholds in soils should be addressed in the future both by the scientific community and in public policy. Several soil extraction methods should be evaluated, considering both total and available $\mathrm{Cu}$ contents in order to reach a robust decision scheme.

\section{Current Challenges}

As described in the previous paragraphs, a deeper understanding of the $\mathrm{Cu}$ accumulation phenomenon in vineyard soil with an all-encompassing approach, including the main environmental and agricultural risks connected, appears necessary. Concurrently, the identification of approaches and the setup of cultivation practices aimed at mitigating the problem are urgent. Therefore, the following paragraphs describe some examples considering recent technological innovations like rhizosphere management, biotechnologies applied to vine plant breeding and smart viticulture.

\subsection{Copper Effects on Soil Agrobiodiversity}

Soil contains a vast underground world inhabited by many fungal and bacterial species. It is estimated that $1 \mathrm{~g}$ of soil contains a number of bacteria ranging between 100,000 to $1,000,000$, and, within this fraction, there may exist different micro-niches in which several ecotypes may live [64,65]. Although only a small fraction of the fungal and bacterial diversity is known, certain fungal and bacterial groups play a crucial role in several agroecosystem services, including plant-growth promotion and cycling of nutrients (e.g., nitrogen, $\mathrm{N}$, and phosphorus, P) [66-68]. However, the accumulation and the excessive availability of heavy metals such as $\mathrm{Cu}$ can impact the soil microbial biomass and activity, thus affecting some microbial-driven soil processes, including $\mathrm{N}$ fixation and mineralization [69]. Moreover, $\mathrm{Cu}$ has been demonstrated to impact microbial 
communities' composition and functionality, with higher effects on bacterial than fungal communities [70-74]. Fungi and bacteria have evolved different strategies against high $\mathrm{Cu}$ concentrations in soils (Figure 3). For instance, some filamentous fungal and yeasts species act against the overload soil $\mathrm{Cu}$, directly at the cytosol level [75]. Herein, the sequestration of the free $\mathrm{Cu}$ ions occurs due to metallothioneins, a family of cysteine-rich proteins (e.g., Cup1 and Crs5) that chelate $\mathrm{Cu}$ [76-78]. Furthermore, when the metal in the cytosol is in excess, fungal cells act through organellar compartmentation of the metal, mainly directing it to the vacuole. Concerning this latter strategy, no specific $\mathrm{Cu}$ transporter catalyzing the transmembrane transport into the vacuole has yet been identified [79]. In addition, cytoplasmic chaperones' activity is essential for mitigating $\mathrm{Cu}$ stress in the cytosol. Indeed, while the chaperone Atx1 delivers $\mathrm{Cu}$ to the trans-Golgi network, $\mathrm{Ccs} 1$ delivers $\mathrm{Cu}$ to the $\mathrm{Cu}-\mathrm{Zn}$ Superoxide dismutase Sod1 [80,81].

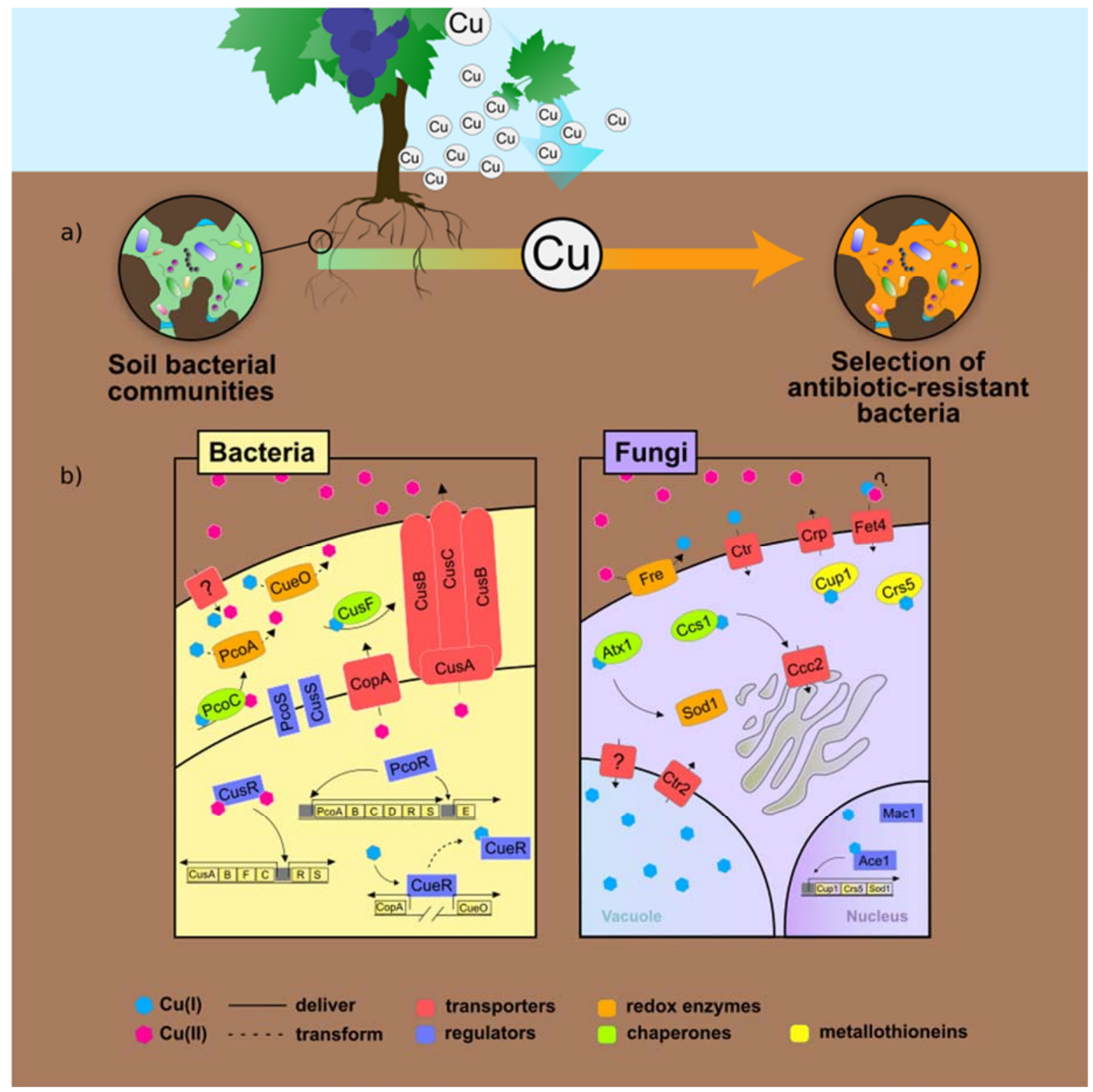

Figure 3. Exposure of soil microorganisms to $\mathrm{Cu}$ in vineyards. (a) Selection of $\mathrm{Cu}$-resistant and antibiotic-resistant genes due to the $\mathrm{Cu}$ application (b) Schematic representation of the bacterial and fungal strategies for coping with excessive Cu inputs; 
In contrast, in bacteria, the detoxification strategy relies mainly on a $\mathrm{Cu}$ export system based on the functionality of two different mechanisms for Gram-positive and Gramnegative bacteria [82]. In Gram-positive bacteria, proteins belonging to the Cop family are at the basis of cytosolic $\mathrm{Cu}$ disposition. The system includes a $\mathrm{Cu}$ chaperone (CopZ) that delivers $\mathrm{Cu}$ first to CopY (copper responsive repressor), activating the transcription of $\operatorname{cop} A$ and $\operatorname{cop} B$ (genes encoding for ATPase pumps), which extrude $\mathrm{Cu}^{+}$and $\mathrm{Cu}^{2+}$ from the cell, respectively. In Gram-negative bacteria, the presence of periplasmic space determines the evolution of specific mechanisms for extruding $\mathrm{Cu}$ in the extracellular space. Specifically, the Cop-protein system is located on the inner membrane and in the inner cell, and its activation is mediated by the MerR-type Cu-responsive transcriptional activator CueR [83]. Additionally, while Gram-positive bacteria mainly use the Cop system, Gram-negative bacteria exploit a trans-envelope extrusion system (CusABC ATPase pumps system) [82]. Additionally, the periplasmic multicopper oxidases (PcoA, $\mathrm{CueO}$ ), oxidizing $\mathrm{Cu}^{+}$to $\mathrm{Cu}^{2+}$ and activating the production of siderophores to sequester the cytoplasmic $\mathrm{Cu}$, play a crucial role in the $\mathrm{Cu}$ detoxification process $[84,85]$.

Moreover, the $\mathrm{Cu}$ accumulation in agricultural soils other than bacterial $\mathrm{Cu}$ resistance can also promote the occurrence of antibiotic resistance, with these traits being linked together [86-90] (Figure 3). Therefore, at the molecular level, the Cu-resistant and antibioticresistant genes can be reasonably co-selected. Thus, they can commonly occur on the same mobile genetic element (i.e., plasmid, integron or transposon) [91,92]. Additionally, the bacteria cells can have a cross-resistance molecular mechanism in which the same gene confers resistance to different antimicrobial agents, such as antibiotics and $\mathrm{Cu}$ [91]. Indeed, the repeated application of $\mathrm{Cu}$ to agricultural soils over the years, given that the metal is not degradable, can dramatically enhance the frequency and dissemination of Cu-resistant and antibiotic-resistant genes [92]. In this context, $\mathrm{Cu}$-contaminated vineyard soils could even be considered a reservoir of antibiotic-resistance traits that can be transferred among the different bacterial species via vertical and horizontal gene transfer (e.g., plasmid-mediated conjugation, integrons) [36]. However, more detailed studies should be carried out to elucidate the possible long-term impact of $\mathrm{Cu}$ on the bacterial communities inhabiting agricultural soils linked to the antibiotic resistance. Indeed, there is a general lack of knowledge about the potential route for the transmission of antibiotic-resistant bacteria from soil to crops, animals and humans. Specifically, it will be crucial to investigate the potential health risk assessment to prevent further development of pathogenic-resistant bacteria in agricultural ecosystems.

\subsection{Soil Management Considering the Root-Microorganism Interactions (Rhizosphere Management)}

Considering the ever-increasing incidence of soils contaminated with $\mathrm{Cu}$, it is evident that rhizosphere dynamics must be taken into account when setting up and applying soil management practices to mitigate the $\mathrm{Cu}$ stress in these agricultural soils. In fact, the biogeochemical cycles of the nutrients completely differ at the soil-root interface compared to non-rooted soil (i.e., bulk soil). Indeed, the highly dynamic interactions between roots, soil and microorganisms occurring in the rhizosphere control not only the speciation and the consequent availability of the nutrients (and, in turn, the extent of their root acquisition), but also determine the level of availability/toxicity of heavy metals like Cu. For instance, in the hotspot that is the rhizosphere, $\mathrm{pH}$ value modifications and the release of low- and high-molecular-weight organic compounds by both roots and microorganisms are the main drivers of $\mathrm{Cu}$ availability.

Concerning soil $\mathrm{pH}$ values, root-induced changes of this chemical parameter are mainly triggered by plant nutrient uptake. This process is often coupled with an active proton extrusion catalyzed by the plasma membrane $\mathrm{H}^{+}$-ATPase [28]. Furthermore, an unbalanced cation/anion uptake of nutrients might lead to either acidification (i.e., due to an excessive uptake of cations) or alkalization (i.e., due to an excessive uptake of anions) of the rhizosphere. These imbalances might occur naturally due to different plant requirements, depending on the physiological status of the plants, microbial interactions 
and/or competition with neighboring plants, as well as potentially being caused by the unbalanced availability of some nutrients in the growth medium [93,94]. Indeed, in vineyards, when cover crops are co-cultivated with other plants like vine plants, nutrient competition might induce an unbalanced uptake of elements with consequent root-induced changes of the $\mathrm{pH}$. As is to be expected, this phenomenon impacts $\mathrm{Cu}$ mobility/availability and, consequently, its toxicity. On the other hand, excessive concentrations of metals like $\mathrm{Cu}$ might also be themselves responsible for an unbalanced nutrient uptake. Recent studies have highlighted that $\mathrm{Cu}$ stress can induce synergism and/or antagonisms with many other nutrients like $\mathrm{P}, \mathrm{Fe}, \mathrm{Zn}$ and $\mathrm{Mn}$, causing further root-induced $\mathrm{pH}$ changes both in annual grass species and in perennial plants like grapevine $[15,95]$. The complexity is further exacerbated by the fact that rhizosphere effects (like acidification and alkalization processes) are not always constant over time [96] and are strongly plant species and genotype/rootstock dependent $[15,95,96]$.

As mentioned earlier, besides $\mathrm{pH}$ values, rhizosphere organic compounds are the main drivers shaping $\mathrm{Cu}$ speciation in agricultural soils. Indeed, specific compound classes such as phenolic compounds and carboxylic acids play a fundamental role in both internal and external $\mathrm{Cu}$ tolerance strategies of plants [97]. Recent studies have shown that perennial plants like grapevines also trigger their root exudation when exposed to excessive $\mathrm{Cu}$ concentrations, yet the phenomenon strongly depends on the type of the rootstock and the growing conditions [15]. Indeed, when grapevines are intercropped with annual grass species like oat, the exudation pattern is completely modified. Furthermore, the enhanced exudation reduces the $\mathrm{Cu}$ accumulation in grapevine plants, making this a valuable agronomic strategy for mitigating $\mathrm{Cu}$ stress [15]. It is important to highlight that the alleviating effect is highly plant species dependent, and thus the intercropping approach should be evaluated for each specific rootstock. In addition, the intermingling of roots in intercropping systems might induce a competition between plant species leading on one side to a modified exudation profile and on the other side to an unbalanced nutrient uptake ultimately affecting the effect of $\mathrm{Cu}$ stress.

In addition, soil management also comprises fertilization strategies, which also strongly affect rhizosphere dynamics. For instance, the source of $\mathrm{N}$ supply $\left(\mathrm{NO}_{3}{ }^{-}\right.$or $\left.\mathrm{NH}_{4}{ }^{+}\right)$ affects the $\mathrm{pH}$ at the soil-root interface both in annual and perennial plant species [28]. Nitrate-based fertilizers induce an enhanced anion root uptake with proton consumption and a consequent alkalization of the rhizosphere. On the other hand, ammonium-based fertilizers trigger enhanced proton release by roots, resulting in significant rhizosphere acidification. Even though nitrate usually predominates over ammonium in agricultural soils due to the very rapid microbial nitrification processes, preferential ammonium uptake might still occur in acid soils, at low soil temperatures, or shortly after the application of ammonium fertilizers, organic fertilizers and/or nitrification inhibitors [28]. Soil management should thus comprise fertilization-induced root activities, since $\mathrm{Cu}$ availability in soil is strongly $\mathrm{pH}$ dependent and might undergo mobilization processes, exacerbating its toxicity. Moreover, an adequate nutritional balance for a crop seems to be decisive in mitigating the effects of $\mathrm{Cu}$ toxicity when the metal is already present in relevant quantities. Vineyards in calcareous soils represent a clear example. In fact, in this case, the edaphic conditions (essentially soil $\mathrm{pH}$ values) should theoretically restrain the availability of $\mathrm{Cu}$ to the plants. However, if the Fe availability for crops becomes limited as a consequence of the chemical-mineralogical nature of the soil, the activation of the plant's adaptive responses to this deficiency (including the acidification of the rhizosphere [98]) could transform the $\mathrm{Cu}$ problem from potential to real.

The complexity of rhizosphere dynamics highlights that soil management, and particularly the management of nutrients, in agricultural agroecosystems such as vineyards needs a comprehensive overview and an appropriate knowledge of the soil-plant system and its dynamics. Indeed, such knowledge could be crucial in counteracting the negative effects of toxic concentrations of heavy metals like $\mathrm{Cu}$ and/or exploiting beneficial synergism between elements to benefit the agricultural production. Future studies should therefore 
focus on a holistic approach that also includes the third main actor involved in rhizosphere processes, i.e., microorganisms. Even though microorganisms are known to increase plant growth and stress resilience, little is known about the effect of $\mathrm{Cu}$ stress on their composition and functionality in the rhizosphere in real agroecosystems such as vineyards. To date, most studies have been lab-based and recreate artificial metal stress conditions; thus, they still provide an insufficient understanding of the microbiome functioning and the mechanisms of plant-microbiome-soil interactions. Large-scale experiments at the field level are thus essential in order to give a complete overview of the effect of $\mathrm{Cu}$ on the complex interplay between soil, plants and microorganisms involved in the biogeochemical cycles of nutrients at the agroecosystem level.

\subsection{Biotechnologies and Breeding for a More Resistant Plant Material}

Grapevine cultivation and wine production worldwide face challenges posed by the high pressure of fungal and fungal-like diseases, causing production losses [99]. The most common and severe problems in viticulture include those presented by downy mildew and powdery mildew infections, caused by Plasmopara viticola and Erisyphe necator, respectively [100]. Both pathogens are commonly controlled by the application of fungicides in vineyards, mainly based on $\mathrm{Cu}$ [101]. However, the implementation of innovative strategies, such as the use of pathogen-resistant vine genotypes, is highly desirable with the aim of achieving a more sustainable viticulture. For this reason, breeding programs have been implemented in order to transfer the so-called resistance $(R)$ genes from resistant Vitis species to sensitive $V$. vinifera varieties [102].

The production of resistant grapevine hybrids began in the 19th Century, yet the first varieties, obtained from traditional breeding carried a high percentage of non- $V$. vinifera genetic material and presented undesirable "foxy" flavors in the resulting wine, a distinctive feature of $V$. labrusca [101]. In the post-genomic era, new techniques, such as marker-assisted backcrossing, marker-assisted background selection and marker-assisted pyramidization, contributed to the development of breeding strategies allowing the precise introgression of wild alleles in susceptible genomes, while reducing the undesired residual genetic material [103]. At present, up to 27 Quantitative Trait Loci (QTL), known as Rpv genes, are associated with the resistance to P. viticola, while up to 13 QTL (Ren and Run genes) are related to resistance against E. necator [102]. Following infections, Rpv genes can induce different defense responses (e.g., hypersensitive response, the accumulation of phenolic compounds in the infected tissues, the accumulation of callose and lignin, the synthesis of phytoalexins, the induction of either cell necrosis or peroxidase activity; [104] and the references therein), while Ren and Run loci have been shown to encode small gene families of receptor-like proteins that are thought to directly or indirectly interact with pathogen-specific effectors. This interaction elicits a signaling cascade that leads to the transcriptional reprogramming of the host plant and the expression of plant defense genes [105]. Despite the potential economic and environmental benefits achievable, the diffusion of resistant hybrids is being prevented by the wine-making industry, which preferentially chooses traditional genotypes, despite their being susceptible, over resistant ones, mainly because of current regulations [102,106]. A remarkable opportunity to overcome the issues related to traditional breeding might be offered by the genome editing approach, directed towards the susceptibility $(S)$ genes encoded in the V. vinifera genome [107]. The functionality of $S$ genes is required for successful infections by both $E$. necator $[108,109]$ and $P$. viticola $[106,110]$. Indeed, the targeted inactivation of $S$ genes in $V$. vinifera plants might potentially lead to the generation of resistant clones, while still preserving the genetic identity of the parental genotypes, which would be highly appreciated by the wine producing industry [106].

Interestingly, these new varieties can be defined as being tolerant to the pathogens; however, in cases of very high infection pressure, the endogenous plant responses might not be sufficient for counteracting disease, making the application of agrochemicals like $\mathrm{Cu}$ necessary for controlling and/or contrasting pathogen diffusion within the canopy 
(Figure 4). Indeed, despite not completely avoiding the application of fungicides, resistant varieties might contribute to strongly decreasing the use of agrochemicals in open fields.

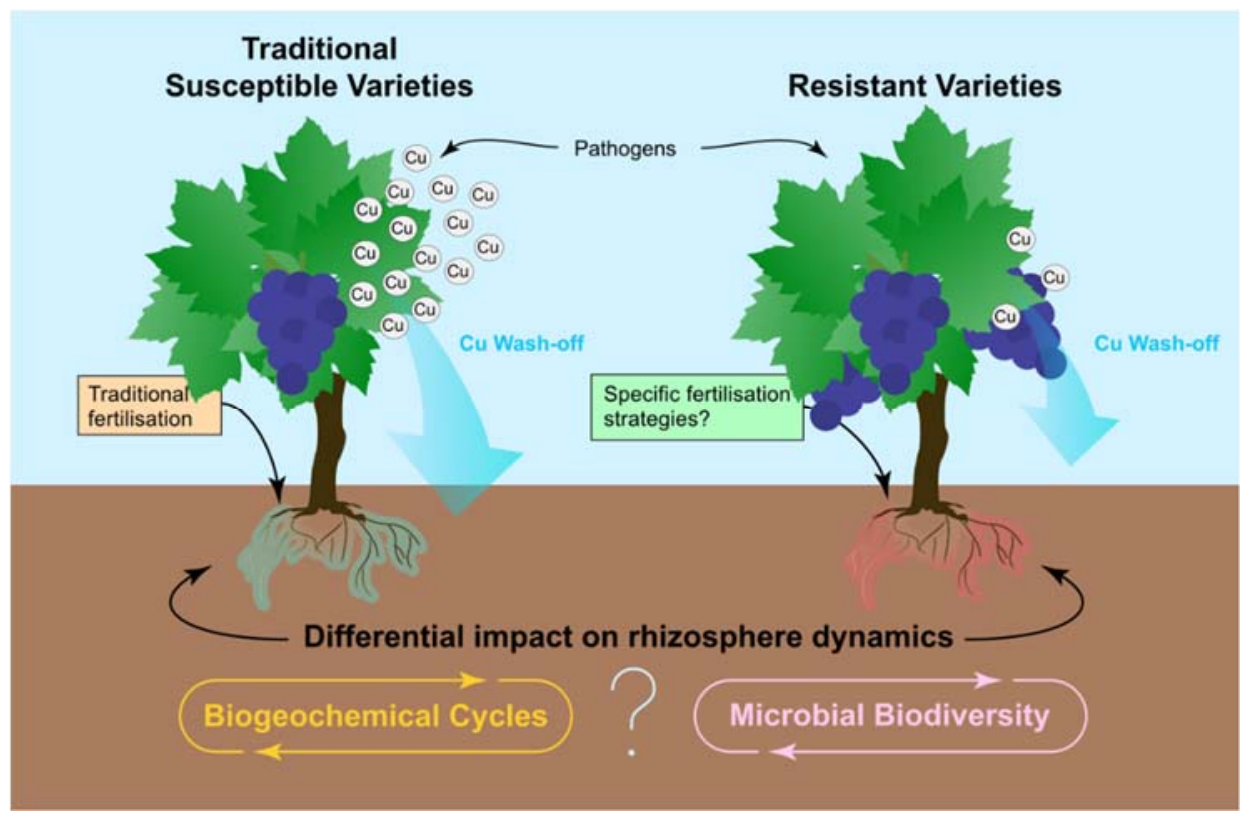

Figure 4. Traditional susceptible varieties vs. resistant varieties in viticulture. The protection of traditional susceptible varieties from pathogen infections requires the repeated application of Cu-based fungicides, which, through drift phenomena and rain wash-offs, can cause a consistent accumulation of $\mathrm{Cu}$ in vineyard soils. The increased $\mathrm{Cu}$ concentration in soil can, on one hand, induce vine plants to modify their exudation to cope with $\mathrm{Cu}$ toxicity, and, on the other hand, promote an alteration of soil microbial biodiversity. The combination of modified exudation patterns with an altered rhizosphere microbial community might impact the biogeochemical cycles of mineral nutrients, thus modifying their availability to plants. In resistant varieties, the protection against pathogens requires lower application rates of agrochemicals, thus also reducing the input of $\mathrm{Cu}$. Nonetheless, the expression of the resistance gene(s) might alter the physiology of vine plants at transcriptomic, proteomic and metabolomic levels, in this case also causing a modification in the exudation pattern. In addition, evidence shows that resistant varieties might require specific fertilization strategies in order to fully present the resistance traits. Again, an altered exudation pattern combined with the input, albeit minimal of $\mathrm{Cu}$ and fertilizers may impact the rhizosphere dynamics, affecting both soil microbial biodiversity and the biogeochemical cycles of mineral elements.

Nevertheless, both the introgression of foreign genetic material (such as for traditional breeding) and the silencing of genes (such as for the genome editing approach) could potentially alter the physiology of plants. The modification of vine plants' genetic material might produce, for instance, organisms that could require particular edaphic conditions (e.g., specific fertilization practices and/or specific provision of micro/macronutrients) in order to express disease resistance at optimum levels (Figure 4). In fact, specific nutrient fluxes within the leaf blade seem to be the basis for the expression of the pathogen response in these resistant varieties [111]. In addition, transcriptional reprogramming, as in the case of either Rpv or Ren/Run loci, can alter the metabolome [112,113], which might mirror modifications in qualitative and quantitative root exudation patterns. Root rhizodeposition plays a crucial role in the transformations and fluxes of nutrients from soil to plant [114], considerably affecting the extent of their acquisition by plants, and therefore, the crop yield. Moreover, root exudates represent, at least in part, the mechanism by which plants can recruit soil microbiota and shape the rhizosphere microbial community [115]. As mentioned earlier, this could either directly or indirectly impact the structure, the diversity and the functionality of soil and rhizosphere microbial communities, which play a pivotal 
role in the processes occurring below ground (Figure 3) [68,115-117]. In this regard, the accidental selection of pathogenic microbes, which could represent a future challenge for viticulture in terms of new plant diseases, cannot be excluded. Therefore, the suitability assessment of these new plant materials should not be limited to those traits that are strictly connected with the expression of the pathogen resistance genes for the purpose of overcoming old (i.e., the classical and well-recognized vine diseases) challenges. Indeed, it is necessary to evaluate resistant varieties also with respect to putative new challenges (i.e., new pathogens and the related diseases) in order to establish the sustainability of these viticultural practices in both the short and the long term. Furthermore, the availability of rootstocks with traits of tolerance to $\mathrm{Cu}$ toxicity could be advantageous in viticultural areas. Finally, the increase in phenotype and genotype data of the scions and the rootstocks could significantly benefit from the application of machine learning to accelerate the crop breeding process [118] in press).

\subsection{Smart Viticulture}

$\mathrm{Cu}$ accumulation in soil can be restrained through direct (e.g., using more resistant plant species, as described in the previous paragraph) and indirect actions (e.g., decreasing the availability in the rhizosphere and/or limiting the quantity of $\mathrm{Cu}$ that reaches the soil via new applications). Since the resistant varieties of vine plants currently available are essentially tolerant, and therefore a certain level of plant defense using pesticides is essential, indirect actions are still important not only for the traditional varieties, but also for the new ones. In this respect, the main goal is to avoid drift phenomena during the application of pesticides and to limit $\mathrm{Cu}$ accumulation in the soil. The $\mathrm{Cu}$ applied to the vine canopy will indeed reach the soil due to rain, foliar irrigation and/or autumn leaf fall.

In the last two decades, a wide range of technologies have been increasingly applied in viticulture, such as monitoring technologies, decision support systems and operating technologies. Monitoring technologies include geolocation, remote sensing (using satellites, aircrafts, and unmanned aerial vehicle/drone images), and proximal sensing during production (using wireless sensor networks to measure soil moisture, leaf wetness, grape temperature, sap flow, etc.) and harvesting phases (using volumetric grape sensors and optical sensors for grape "quality"). Decision support systems (DSS) make it possible to consider the spatial variability (i.e., the variability of soil properties, landscape features, crop stresses, yield and quality in the different areas of a field [119]) in process optimization (irrigation, fertilization, or chemical treatments) and harvesting. Finally, operating technologies include variable-rate technologies (VRT) and agricultural robots, which make it possible to implement the activities defined with the help of the DSS, while also limiting drift phenomena [120].

These technologies were proposed in the 1990s, initially for their ability to manage crops according to site-specific logic, which makes it possible to deal with the spatial variability of soil, nutrient and phytosanitary conditions. They also include geo-referencing, which allows producers to micro-manage soil and plant processes within small areas of a single field. Despite positive expectations, these techniques' diffusion is still relatively limited, as several authors have reported [121-125]. In several European countries, the use of ITC in agriculture remains at less than $10 \%$ of farms, and, of these, only $50 \%$ of farms that complete site-specific applications. The current circumstances are considered to be very favorable for the growth of the sector, not only for the new generation, with habits more rooted in the use of digital technologies, but also for the "cultural dragging" caused by the so-called "Industry 4.0" revolution [126-128]. In fact, this revolution has brought significant attention to the new technological frontiers connected to the "Internet of Things" (IoT), Big Data, Cloud Computing, hyper-connectivity, cybernetics and augmented reality. As a consequence of this technological trend and its effects, the terms agriculture 4.0 and smart agriculture are coming to be preferred to the term precision agriculture [129].

To the best of our knowledge, there are no studies measuring the exact impact of precision or smart viticulture techniques on the limitation of $\mathrm{Cu}$ accumulation/toxicity 
at the soil level. However, various papers have highlighted that the goal of these techniques is to improve not only the yield and quality of grape production, but also its environmental sustainability (i.e., reducing the chemical treatments) $[120,130]$. Indeed, these techniques have shown that it is possible to reduce the use of $\mathrm{Cu}$-based fungicides by $25-50 \%$ [131-133]. Therefore, it can be expected that the contribution to the limitation of $\mathrm{Cu}$ accumulation/toxicity at the soil level will be remarkable. Thus, a set of examples of precision and smart viticulture technologies (which might be used by practitioners and scholars as an initial reference point for implementation projects and precise impact analyses) is discussed in the following paragraphs. Other examples can be found in the detailed reviews of literature and field applications of precision viticulture [120] or precision agriculture [134-136].

While soil protection has mostly been studied using a mono-disciplinary approach (e.g., soil chemistry, plant defense), the use of precision/smart viticulture technologies in combination with an interdisciplinary approach involving technology experts (from the fields of sensors, electronics, computer science, and agricultural machinery), domainexperts (e.g., from the fields of soil chemistry, plant pathology, genetics, and agronomy) and sustainability experts (or Lifecycle assessment experts) is increasingly needed.

In particular, precision and smart viticulture technologies could contribute positively to the following aspects: (1) crop monitoring, i.e., using optical sensors on vehicles (e.g., tractors, autonomous vehicles, or drones) to perform a sort of "early digital scouting" to be carried out promptly to keep the phytosanitary status of wide-crop areas under control [137,138]; (2) operational monitoring, i.e., using the so-called FORK systems (Field Operation Register Keeping) $[129,139,140]$ which allow the detection and automatic recording of how a field operation is carried out; (3) implementation of site-specific techniques with retrofit components, i.e., adaptable to existing farm machinery, thus avoiding the need to make large investments in new equipment (see Figure 5). The first two aspects concern information management actions, necessary for medium- and long-term quality decision-making processes at the farm, based on targeted information. The third aspect allows a direct intervention with immediate control effects, especially if the retrofit device is also equipped with sensors capable of locally estimating the volumes of canopy to be treated and then enabling the adjustment of the doses to be distributed accordingly.

Sensors installed both on agricultural machines and within the vineyards (both at the plant and soil level) allow the collection and monitoring of data (e.g., the color, shape and dimensions of leaves and grapes, temperature and weather conditions, soil $\mathrm{pH}$, and the presence of pathogens $[120,130,131,141])$. These data can then be processed (cleaned, filtered, aggregated, represented and archived) and analyzed to extract the relevant information. These analyses might be carried out by a DSS at the farm or at external servers accessible over the Internet (i.e., in the Cloud) $[133,141]$. Moreover, they might be automated through Artificial Intelligence and/or neural networks algorithms, and they might also be used to simulate/prevent future behaviors/events (e.g., a digital twin of the vineyards can be created where the impact of different interventions/strategies can be simulated) [142]. The data analyses might also combine data from multiple farms/vineyards, as well as other big (information assets characterized by such a high volume, velocity and variety that it requires specific technology and analytical methods for its transformation into value [143]) data from several sources [144,145]. Finally, the results obtained can lead to an action, such as process optimization (modification of irrigation, fertilization, or chemical treatments), or to a report for internal or external users $[129,131,133]$. Such actions can also be implemented in a more precise and/or automatic way through straddle tractors/machines, autonomous vehicles/robots, and drones $[120,146]$. Finally, the application of these technologies might help the winegrower to spray, fertilize or irrigate (1) when it is needed; (2) exactly where it is needed (also limiting the drift); and (3) at the quantity needed in the different areas of the field and times (i.e., considering the horizontal, vertical, and spatial variability), thus potentially minimizing the $\mathrm{Cu}$ accumulation process in the soil. The technologies presented above are (mostly) already available on the market 
and have been adopted by some vineyards. An interesting example of this is PlantCT ${ }^{\mathrm{TM}}$ (formerly known as Smartvineyard), a system that continuously monitors the plants and the environment using a wide range of sensors (i.e., spore and pest detectors, as well as leaf surface, light, humidity, and temperature, wind, solar radiation, precipitation and soil sensors) and suggests to the winegrower the interventions/actions that should be implemented (https:/ / plantct.com/). Another example-more focused on the topic of this paper-is Coptimizer, a model-driven DSS that might help to optimize and track the use of Cu-based fungicides in viticulture. Other similar examples include VineSens [141], GRover [147], and FeelGrid ${ }^{\mathrm{TM}}$ (https://www.feelgrid.com/). For a detailed review of smartphone applications for smart agriculture, see [148]. There are then several companies producing variable-rate (or smart) straddle tractors/machines and spraying drone systems (also) for vineyard applications (e.g., Pellenc, New Holland, Durand-Wayland, Tecnovit, Fly Dragon Drone Tech., Chouette). Some of these systems have been presented in detail by [120].

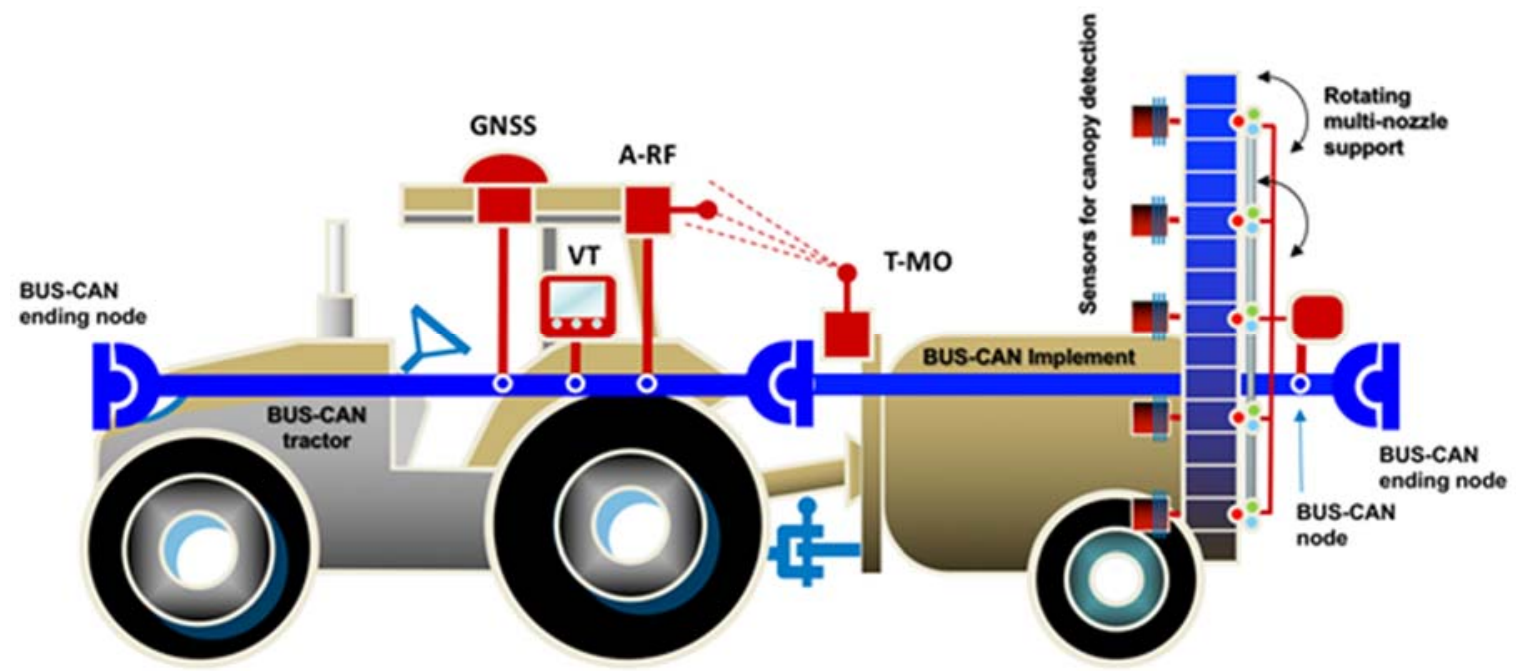

Figure 5. Design of a possible retrofit device to be applied to sprayers already present at the vineyard to enable them to operate according to site-specific logics. The retrofit application concerns a vertical spraying tower equipped with a set of rotating supports for independent nozzle selection and activation. The control is supported by a set of volumetric ultrasonic sensors able to detect the size of the canopy to be processed. The solution even includes a Field Operation Register Keeping (FORK) system based on an identification device enabling the tractor to automatically detect the identity of the coupled machine through a simple Radio Frequency (RF) system (T-MO: implement transmitting code; A-RF: tractor receiving antenna; identification is enabled only on distances $<20 \mathrm{~m}$ ). On board data transmission is performed via Controller Area Network (BUS-CAN), supposing this is already available on-board. In case of older tractors (no BUS-CAN), a direct wire connection can be easily established.

The necessary investments and/or operating costs required by the abovementioned systems - as well as more generally for the implementation smart farming solutions-are, however, rather high, particularly for small vineyards $[149,150]$. Furthermore, specific know-how is often needed to properly use them [149]. The Industry 3.0 phase (indicatively occurring between 1970 and 2010) was characterized by digital culture and technologies in the management of industrial production processes. On the other hand, the Agriculture 3.0 phase (occurring between 1980 and 2000) introduced technological innovations mainly focused on the improvement of the quality of mechanization in the fields of electronics, ergonomics and safety, but with limited results in the field of information technology. The "digital gap" in agriculture compared with the industrial sector is particularly relevant. Therefore, the key challenge is to adopt these systems and technologies for economic sustainability (the retrofit idea mentioned above could, for instance, be an interesting solution) and to explain their potential benefits to winegrowers. Another possible idea could be 
the creation of some consortia or cooperative forms to cover the high investments/costs. In any case, with the application of these strategies, it is possible to significantly limit the supply of $\mathrm{Cu}$ to the vineyard, thus limiting the metal accumulation process in the wine-growing context.

However, future research is needed on the smart viticulture topic at different levels to contribute to the general challenge. First, while well-developed and robust solutions for specific purposes exist (e.g., grape yield monitors, soil and leaf monitors and precision sprayers), they still tend to work as separate silos. Future research should therefore try to develop visions as well as practical architectures/applications for an integrated smart (or digital) management of vineyards. Second, there is a strong need to identify the competencies needed by farmers (and by wine-growing consultants) in order to correctly and effectively use the technologies available and to consequently update the study programs. Finally, smart viticulture's impact on the three sustainability dimensions (i.e., environmental, social and economic) should be further investigated. [151] showed that both positive and negative impacts of Industry 4.0 technologies can be observed in the industrial field. This might also be applied in viticulture (and, more generally, in agriculture) where, to date, research has mostly focused on the environmental dimension [130,131].

\section{Conclusions}

The repeated application of copper $(\mathrm{Cu})$-based fungicides in conventional and organic farming has caused a significant increase in the total $\mathrm{Cu}$ contents in vineyard soils, posing agricultural and environmental threats. The goal of our review was to shed light on this issue and to discuss some approaches that might be adopted to limit $\mathrm{Cu}$ toxicity.

We presented the current $\mathrm{Cu}$ accumulation situation, with particular reference to the European context (see Figure 1), and discussed its potential risks in viticulture (see Figure 2), considering the chemical-physical-microbiological properties of soils, as well as the toxicity phenomena in plants. Furthermore, some approaches and setups of cultivation practices aimed at mitigating the $\mathrm{Cu}$ accumulation problem (namely, rhizosphere management, biotechnologies and breeding for more resistant plant material, as well as precision/smart viticulture techniques for a timely, localized and balanced distribution of agrochemicals) were discussed. We summarized the current literature for all these topics and highlighted a set of research gaps that urgently require future studies and innovation. In particular, research is needed to shed light on the possible long-term impacts of $\mathrm{Cu}$ on selecting antibiotic-resistant bacterial species of agricultural soils and on their potential threats to animal and human health. Future studies should then focus on vineyard rhizosphere dynamics more holistically, i.e., considering the microorganisms and the effect of $\mathrm{Cu}$ stress on their composition and functionality, as well as relying on large-scale experiments at the field level. Third, the assessment of "new" resistant plant material (scions) should not be limited to the traits strictly connected with the expression of the pathogen resistance genes for overcoming current vine diseases, but should also consider putative new pathogens and related diseases. From this perspective, particular attention should also be paid to rootstocks with tolerance traits for high $\mathrm{Cu}$ concentrations in soils. Finally, future research is needed (1) to develop visions as well as practical architectures/applications for an integrated smart (or digital) management of the vineyard; (2) to identify the competencies needed by farmers and wine-growing consultants to use the technologies available correctly and effectively; and (3) to shed empirical light on the impact of smart viticulture on the three sustainability pillars (i.e., environmental, social and economic).

More generally, our review showed that the setting up of a more sustainable soil management in viticulture requires a multidisciplinary approach involving all the players throughout the whole production chain. In this context, the availability of plant material more resistant to pathogens and physiologically more suitable for the edaphic environment is essential. Moreover, $\mathrm{Cu}$-induced antibiotic resistance in soil microorganisms highlights the relevance of the One Health concept, where the protection of plant, animal and human health is considered to be one. For instance, the frequent contamination of the water sources 
used for crop irrigation with synthetic compounds for human care (such as drugs like ibuprofen, [152] clearly indicates that the defense plan against pathogens of agricultural crops like vines using agrochemicals should not be considered independently of animal and human health, and vice versa. Actually, thanks to an approach like this, it is possible to effectively contribute to both the continuation of the viticulture (and more generally that of agricultural production) and the preservation of the environment as a whole, in particular the soil ecosystem.

Author Contributions: S.C., T.M. and G.O. conceived and designed the review; S.C., Y.P., L.B., G.O., P.L., F.M., G.G., M.S., G.B., R.T., G.V. and T.M. wrote the manuscript. All authors have read and agreed to the published version of the manuscript.

Funding: This research was supported by grants from Free University of Bolzano (TN5056, TN2612, TN2081). We acknowledge support by the unibz Open Access publishing fund, Free University of Bolzano.

Conflicts of Interest: The authors declare that the research was conducted in the absence of any commercial or financial relationships that could be construed as a potential conflict of interest.

\section{References}

1. ONU. World Population Prospects 2019; Department of Economic and Social Affairs: New York, NY, USA, 2019.

2. Meyers, W.H.; Kalaitzandonakes, N. World Population, Food Growth, and Food Security Challenges. Front. Econ. Glob. 2015, 15, 161-177. [CrossRef]

3. Conijn, J.G.; Bindraban, P.S.; Schröder, J.J.; Jongschaap, R.E.E. Can our global food system meet food demand within planetary boundaries? Agric. Ecosyst. Environ. 2018, 251, 244-256. [CrossRef]

4. Indoria, A.K.; Sharma, K.L.; Reddy, K.S. Hydraulic properties of soil under warming climate. Clim. Chang. Soil Interact. 2020, 473-508.

5. González-Alemán, J.J.; Pascale, S.; Gutiérrez-Fernández, J.; Murakami, H.; Gaertner, M.Á.; Vecchi, G.A. Potential Increase in Hazard From Mediterranean Hurricane Activity With Global Warming. Geophys. Res. Lett. 2019, 46, 1754-1764. [CrossRef]

6. Koppelaar, R.H.; Weikard, H. Assessing phosphate rock depletion and phosphorus recycling options. Glob. Environ. Chang. 2013, 23, 1454-1466. [CrossRef]

7. Xie, H.; Huang, Y.; Chen, Q.; Zhang, Y.; Wu, Q. Prospects for Agricultural Sustainable Intensification: A Review of Research. Land 2019, 8, 157. [CrossRef]

8. Miotto, A.; Ceretta, C.A.; Brunetto, G.; Nicoloso, F.T.; Girotto, E.; Farias, J.G.; Tiecher, T.L.; De Conti, L.; Trentin, G. Copper uptake, accumulation and physiological changes in adult grapevines in response to excess copper in soil. Plant Soil 2013, 374, 593-610. [CrossRef]

9. Brunetto, G.; De Melo, G.W.B.; Terzano, R.; Del Buono, D.; Astolfi, S.; Tomasi, N.; Pii, Y.; Mimmo, T.; Cesco, S. Copper accumulation in vineyard soils: Rhizosphere processes and agronomic practices to limit its toxicity. Chemosphere 2016, 162, 293-307. [CrossRef]

10. Oorts, K. Copper. In Heavy Metals in Soils: Trace Metals and Metalloids in Soils and Their Bioavailability; Springer Science + Business Media: Dordrecht, The Netherlands, 2013; pp. 367-394.

11. Shabbir, Z.; Sardar, A.; Shabbir, A.; Abbas, G.; Shamshad, S.; Khalid, S.; Natasha, N.; Murtaza, G.; Dumat, C.; Shahid, M. Copper uptake, essentiality, toxicity, detoxification and risk assessment in soil-plant environment. Chemosphere 2020, $259,127436$. [CrossRef]

12. Blume, H.-P.; Brümmer, G.W.; Fleige, H.; Horn, R.; Kandeler, E.; Kögel-Knabner, I.; Kretzschmar, R.; Stahr, K.; Wilke, B.-M. Chemical Properties and Processes. In Scheffer/Schachtschabel Soil Science; Springer Science and Business Media LLC: Berlin/Heidelberg, Germany, 2016; pp. 123-174.

13. Astolfi, S.; Pii, Y.; Mimmo, T.; Lucini, L.; Miras-Moreno, B.; Coppa, E.; Violino, S.; Celletti, S.; Cesco, S. Single and Combined Fe and S Deficiency Differentially Modulate Root Exudate Composition in Tomato: A Double Strategy for Fe Acquisition? Int. J. Mol. Sci. 2020, 21, 4038. [CrossRef]

14. Bernal, M.; Casero, D.; Singh, V.; Wilson, G.T.; Grande, A.; Yang, H.; Dodani, S.C.; Pellegrini, M.; Huijser, P.; Connolly, E.L.; et al. Transcriptome Sequencing Identifies SPL7-Regulated Copper Acquisition Genes FRO4/FRO5 and the Copper Dependence of Iron Homeostasis in Arabidopsis. Plant Cell 2012, 24, 738-761. [CrossRef] [PubMed]

15. Marastoni, L.; Sandri, M.; Pii, Y.; Valentinuzzi, F.; Brunetto, G.; Cesco, S.; Mimmo, T. Synergism and antagonisms between nutrients induced by copper toxicity in grapevine rootstocks: Monocropping vs. intercropping. Chemosphere 2019, 214, 563-578. [CrossRef]

16. Yuan, M.; Li, X.; Xiao, J.; Wang, S. Molecular and functional analyses of COPT/Ctr-type copper transporter-like gene family in rice. BMC Plant Biol. 2011, 11, 69. [CrossRef]

17. Korshunova, Y.O.; Eide, D.; Clark, W.G.; Guerinot, M.L.; Pakrasi, H.B. The IRT1 protein from Arabidopsis thaliana is a metal transporter with a broad substrate range. Plant Mol. Biol. 1999, 40, 37-44. [CrossRef] 
18. Wintz, H.; Fox, T.; Wu, Y.-Y.; Feng, V.; Chen, W.; Chang, H.-S.; Zhu, T.; Vulpe, C. Expression Profiles of Arabidopsis thalianain Mineral Deficiencies Reveal Novel Transporters Involved in Metal Homeostasis. J. Biol. 2003, 278, 47644-47653.

19. Yruela, I. Copper in plants. Braz. J. Plant Physiol. 2005, 17, 145-156. [CrossRef]

20. Tsai, H.-H.; Schmidt, W. One way. Or another? Iron uptake in plants. New Phytol. 2017, 214, 500-505. [CrossRef]

21. Deng, F.; Yamaji, N.; Xia, J.; Ma, J.F. A Member of the Heavy Metal P-Type ATPase OsHMA5 Is Involved in Xylem Loading of Copper in Rice. Plant Physiol. 2013, 163, 1353-1362. [CrossRef]

22. DiDonato, R.J.; Roberts, L.A.; Sanderson, T.; Eisley, R.B.; Walker, E. Arabidopsis Yellow Stripe-Like2 (YSL2): A metal-regulated gene encoding a plasma membrane transporter of nicotianamine-metal complexes. Plant J. 2004, 39, 403-414. [CrossRef]

23. Irtelli, B.; Petrucci, W.A.; Navari-Izzo, F. Nicotianamine and histidine/proline are, respectively, the most important copper chelators in xylem sap of Brassica carinata under conditions of copper deficiency and excess. J. Exp. Bot. 2008, 60, 269-277. [CrossRef]

24. Liao, M.T.; Hedley, M.J.; Woolley, D.J.; Brooks, R.R.; Nichols, M.A. Copper uptake and translocation in chicory ( Cichorium intybus L. cv. Grasslands Puna) and tomato (Lycopersicon esculentum Mill. cv. Rondy) plants grown in NFT system. I. Copper uptake and distribution in plants. Plant Soil 2000, 221, 135-142. [CrossRef]

25. Cao, Y.; Ma, C.; Chen, H.; Zhang, J.; White, J.C.; Chen, G.; Xing, B. Xylem-based long-distance transport and phloem remobilization of copper in Salix integra Thunb. J. Hazard. Mater. 2020, 392, 122428. [CrossRef] [PubMed]

26. Ryan, B.M.; Kirby, J.K.; Degryse, F.; Harris, H.; McLaughlin, M.J.; Scheiderich, K. Copper speciation and isotopic fractionation in plants: Uptake and translocation mechanisms. New Phytol. 2013, 199, 367-378. [CrossRef] [PubMed]

27. Printz, B.; Lutts, S.; Hausman, J.-F.; Sergeant, K. Copper Trafficking in Plants and Its Implication on Cell Wall Dynamics. Front. Plant Sci. 2016, 7, 601. [CrossRef]

28. Marschner, H.; Nutrition, M.; Plants, H.; Africa, W.; Marschner, P. Marschner's Mineral Nutrition of Higher Plants; Elsevier: Amsterdam, The Netherlands, 2012.

29. Taiz, L.; Zeiger, E. Plant Physiology and Development; Sinauer Associates, Inc.: Sunderland, MA, USA, 2015.

30. Kabata-Pendias, A. Trace Elements in Soils and Plants, 4th ed.; CRC Press: Boca Raton, FL, USA, 2010.

31. Tiecher, T.L.; Tiecher, T.; Ceretta, C.A.; Ferreira, P.A.; Nicoloso, F.T.; Soriani, H.H.; Tassinari, A.; Paranhos, J.T.; De Conti, L.; Brunetto, G. Physiological and nutritional status of black oat (Avena strigosa Schreb.) grown in soil with interaction of high doses of copper and zinc. Plant Physiol. Biochem. 2016, 106, 253-263. [CrossRef]

32. Ambrosini, V.G.; Rosa, D.; De Melo, G.W.B.; Zalamena, J.; Cella, C.; Simão, D.G.; Da Silva, L.S.; Dos Santos, H.P.; Toselli, M.; Tiecher, T.L.; et al. High copper content in vineyard soils promotes modifications in photosynthetic parameters and morphological changes in the root system of 'Red Niagara' plantlets. Plant Physiol. Biochem. 2018, 128, 89-98. [CrossRef]

33. Morgan, R.K.; Bowden, R. Copper accumulation in soils from two different-aged apricot orchards in Central Otago, New Zealand. Int. J. Environ. Stud. 1993, 43, 161-167. [CrossRef]

34. Novak, J.M.; Watts, D.; Stone, K.C. Copper and zinc accumulation, profile distribution, and crop removal in coastal plain soils receiving long-term, intensive applications of swine manure. Trans. ASAE 2004, 47, 1513-1522. [CrossRef]

35. Huang, S.; Jin, J.-Y. Status of heavy metals in agricultural soils as affected by different patterns of land use. Environ. Monit. Assess. 2007, 139, 317-327. [CrossRef]

36. Li, B.; Qiu, Y.; Song, Y.; Lin, H.; Yin, H. Dissecting horizontal and vertical gene transfer of antibiotic resistance plasmid in bacterial community using microfluidics. Environ. Int. 2019, 131, 105007. [CrossRef]

37. Horsfall, J.G. Fungicides and Their Action. J. AOAC Int. 1946, 29, 116-117. [CrossRef]

38. Millardet, A.; Gayon, U. The Discovery of Bordeaux Mixture: Three Papers: I. Treatment of Mildew and Rot. II. Treatment of Mildew with Copper Sulphate and Lime Mixture. III. Concerning the History of the Treatment of Mildew with Copper Sulphate; American Phytopathological Society: Saint Paul, MN, USA, 1933.

39. Mirlean, N.; Roisenberg, A.; Chies, J.O. Metal contamination of vineyard soils in wet subtropics (southern Brazil). Environ. Pollut. 2007, 149, 10-17. [CrossRef] [PubMed]

40. Fernández-Calviño, D.; Nóvoa-Muñoz, J.C.; Díaz-Raviña, M.; Arias-Estévez, M. Copper accumulation and fractionation in vineyard soils from temperate humid zone (NW Iberian Peninsula). Geoderma 2009, 153, 119-129. [CrossRef]

41. Mackie, K.; Müller, T.; Zikeli, S.; Kandeler, E. Long-term copper application in an organic vineyard modifies spatial distribution of soil micro-organisms. Soil Biol. Biochem. 2013, 65, 245-253. [CrossRef]

42. Ballabio, C.; Panagos, P.; Lugato, E.; Huang, J.-H.; Orgiazzi, A.; Jones, A.; Fernández-Ugalde, O.; Borrelli, P.; Montanarella, L. Copper distribution in European topsoils: An assessment based on LUCAS soil survey. Sci. Total Environ. 2018, 636, 282-298. [CrossRef]

43. Dagostin, S.; Schärer, H.-J.; Pertot, I.; Tamm, L. Are there alternatives to copper for controlling grapevine downy mildew in organic viticulture? Crop. Prot. 2011, 30, 776-788. [CrossRef]

44. Regulation 1981/2018. Renewing the Approval of the Active Substances Copper Compounds, as Candidates for Substitution, in Accordance with Regulation (EC) No 1107/2009 of the European Parliament and of the Council Concerning the Placing of Plant Protection Products on the Market, and Amending the Annex to Commission Implementing Regulation (EU) No $540 / 2011$. European Commission, Council of the European Union. Available online: https:// eur-lex.europa.eu/legal-content/EN/TXT/ ?uri=CELEX\%3A32018R1981 (accessed on 9 January 2021). 
45. La Torre, A.; Righi, L.; Iovino, V.; Battaglia, V. Control of late blight in organic farming with low copper dosages or natural products as alternatives to copper. Eur. J. Plant Pathol. 2019, 155, 769-778. [CrossRef]

46. Kopittke, P.M.; Menzies, N.W. Effect of Cu Toxicity on Growth of Cowpea (Vigna unguiculata). Plant Soil 2006, 279, 287-296. [CrossRef]

47. Guimarães, P.R.; Ambrosini, V.G.; Miotto, A.; Ceretta, C.A.; Simão, D.G.; Brunetto, G. Black Oat (Avena strigosa Schreb.) Growth and Root Anatomical Changes in Sandy Soil with Different Copper and Phosphorus Concentrations. Water Air Soil Pollut. 2016, 227, 1-10. [CrossRef]

48. Baldi, E.; Miotto, A.; Ceretta, C.A.; Quartieri, M.; Sorrenti, G.; Brunetto, G.; Toselli, M. Soil-applied phosphorous is an effective tool to mitigate the toxicity of copper excess on grapevine grown in rhizobox. Sci. Hortic. 2018, 227, 102-111. [CrossRef]

49. Feil, S.B.; Pii, Y.; Valentinuzzi, F.; Tiziani, R.; Mimmo, T.; Cesco, S. Copper toxicity affects phosphorus uptake mechanisms at molecular and physiological levels in Cucumis sativus plants. Plant Physiol. Biochem. 2020, 157, 138-147. [CrossRef] [PubMed]

50. Del Buono, D.; Terzano, R.; Panfili, I.; Bartucca, M.L. Phytoremediation and detoxification of xenobiotics in plants: Herbicidesafeners as a tool to improve plant efficiency in the remediation of polluted environments. A mini-review. Int. J. Phytoremediation 2020, 22, 789-803. [CrossRef] [PubMed]

51. International Organization of Vine and Wine, 2020. Current Situation Of The Vitivinicultural Sector At A Global Level. Available online: http:/ / www.oiv.int/js/lib/pdfjs/web/viewer.html?file=/public/medias/7260/en-oiv-press-conference-april-2020 -press-release.pdf (accessed on 18 November 2020).

52. Benoît, L.; William, A.; Lindsey, H.; Adrienne, L.F.; Marianne, M.W. Wine Sector: Definitions and Nuances from Global to Country Analysis-A Comparison between Old World, New World, and Emerging Wine Countries from 2005 to Current; Elsevier BV: Amsterdam, The Netherlands, 2019; pp. 7-32.

53. European Commission. Council Regulation (EC) No 479/2008. Off. J. Eur. Union. 2008, 148, 1-61.

54. European Parliament and of the Council. EU regulation No 1308/2013. Off. J. Eur. Communities 2008, $347,1-22$.

55. Meloni, G.; Anderson, K.; Deconinck, K.; Swinnen, J. Wine Regulations. Appl. Econ. Perspect. Policy 2019, 41, 620-649. [CrossRef]

56. Jones, G.V.; Webb, L.B. Climate Change, Viticulture, and Wine: Challenges and Opportunities. J. Wine Res. 2010, 21, 103-106. [CrossRef]

57. Vigl, L.E.; Schmid, A.; Moser, F.; Balotti, A.; Gartner, E.; Katz, H.; Quendler, S.; Ventura, S.; Raifer, B. Upward shifts in elevation-a winning strategy for mountain viticulture in the context of climate change? E3S Web Conf. 2018, 50, 02006. [CrossRef]

58. Couto, R.D.R.; Benedet, L.; Comin, J.J.; Filho, P.B.; Martins, S.R.; Gatiboni, L.C.; Radetski, M.; De Valois, C.M.; Ambrosini, V.G.; Brunetto, G. Accumulation of copper and zinc fractions in vineyard soil in the mid-western region of Santa Catarina, Brazil. Environ. Earth Sci. 2014, 73, 6379-6386. [CrossRef]

59. Carlon, C. Derivation methods of soil screening values in Europe: A review and evaluation of national procedures towards harmonization. In JRC Scientific and Technical Reports; Office for Official Publications of the European Communities: Luxembourg, 2007.

60. Komárek, M.; Čadková, E.; Chrastný, V.; Bordas, F.; Bollinger, J.-C. Contamination of vineyard soils with fungicides: A review of environmental and toxicological aspects. Environ. Int. 2010, 36, 138-151. [CrossRef]

61. Mackie, K.; Müller, T.; Kandeler, E. Remediation of copper in vineyards-A mini review. Environ. Pollut. 2012, 167, 16-26. [CrossRef]

62. Italian Ministry for Environment Land and Sea Protection. DECRETO 1 Marzo 2019, n. 46; Italian Ministry for Environment Land and Sea Protection: Rome, Italy, 2019.

63. Vácha, R.; Sanka, M.; Hauptman, I.; Zimova, M.; Čechmánková, J. Assessment of limit values of risk elements and persistent organic pollutants in soil for Czech legislation. Plant Soil Environ. 2014, 60, 191-197. [CrossRef]

64. Dykhuizen, D. Species Numbers in Bacteria. Proc. Calif. Acad. Sci. 2005, 56, 62-71.

65. Schmidt, T.; Waldron, C. Microbial Diversity in Soils of Agricultural Landscapes and Its Relation to Ecosystem Function. In The Ecology of Agricultural Landscapes: Long-term Research on the Path to Sustainability; Oxford University Press: New York, NY, USA, 2015; pp. 135-157.

66. Bennett, A.E.; Classen, A.T. Climate change influences mycorrhizal fungal-plant interactions, but conclusions are limited by geographical study bias. Ecology 2020, 101, e02978. [CrossRef]

67. Pii, Y.; Mimmo, T.; Tomasi, N.; Terzano, R.; Cesco, S.; Crecchio, C. Microbial interactions in the rhizosphere: Beneficial influences of plant growth-promoting rhizobacteria on nutrient acquisition process. A review. Biol. Fertil. Soils 2015, 51, 403-415. [CrossRef]

68. Rolli, E.; Marasco, R.; Saderi, S.; Corretto, E.; Mapelli, F.; Cherif, A.; Borin, S.; Valenti, L.; Sorlini, C.; Daffonchio, D. Root-associated bacteria promote grapevine growth: From the laboratory to the field. Plant Soil 2016, 410, 369-382. [CrossRef]

69. Abdu, N.; Abdullahi, A.A.; Abdulkadir, A. Heavy metals and soil microbes. Environ. Chem. Lett. 2017, 15, 65-84. [CrossRef]

70. Dell'Amico, E.; Mazzocchi, M.; Cavalca, L.; Allievi, L.; Andreoni, V. Assessment of bacterial community structure in a long-term copper-polluted ex-vineyard soil. Microbiol. Res. 2008, 163, 671-683. [CrossRef]

71. Giller, K.E.; Witter, E.; McGrath, S.P. Heavy metals and soil microbes. Soil Biol. Biochem. 2009, 41, 2031-2037. [CrossRef]

72. Lejon, D.P.; Pascault, N.; Ranjard, L. Differential copper impact on density, diversity and resistance of adapted culturable bacterial populations according to soil organic status. Eur. J. Soil Biol. 2010, 46, 168-174. [CrossRef]

73. Borruso, L.; Zerbe, S.; Brusetti, L. Bacterial community structures as a diagnostic tool for watershed quality assessment. Res. Microbiol. 2015, 166, 38-44. [CrossRef] 
74. Cavani, L.; Manici, L.M.; Caputo, F.; Peruzzi, E.; Ciavatta, C. Ecological restoration of a copper polluted vineyard: Long-term impact of farmland abandonment on soil bio-chemical properties and microbial communities. J. Environ. Manag. 2016, 182, 37-47. [CrossRef]

75. Vest, K.E.; Zhu, X.; Cobine, P.A. Copper Disposition in Yeast. In Clinical and Translational Perspectives on WILSON DISEASE; Elsevier BV: Amsterdam, The Netherlands, 2019; pp. 115-126.

76. Winge, D.R.; Nielson, K.B.; Gray, W.R.; Hamer, D.H. Yeast metallothionein. J. Biol. Chem. 1985, 260, 14464-14470. [CrossRef]

77. Culotta, V.C.; Howard, W.R.; Liu, X.F. CRS5 encodes a metallothionein-like protein in Saccharomyces cerevisiae. J. Biol. Chem. 1994, 269, 25295-25302. [CrossRef]

78. Jensen, L.T.; Howard, W.R.; Strain, J.J.; Winge, D.R.; Culotta, V.C. Enhanced Effectiveness of Copper Ion Buffering by CUP1 Metallothionein Compared with CRS5 Metallothionein inSaccharomyces cerevisiae. J. Biol. Chem. 1996, 271, 18514-18519. [CrossRef]

79. Gerwien, F.; Skrahina, V.; Kasper, L.; Hube, B.; Brunke, S. Metals in fungal virulence. FEMS Microbiol. Rev. 2018, 42, 1-21. [CrossRef]

80. Carroll, M.C.; Girouard, J.B.; Ulloa, J.L.; Subramaniam, J.R.; Wong, P.C.; Valentine, J.S.; Culotta, V.C. Mechanisms for activating $\mathrm{Cu}-$ and Zn-containing superoxide dismutase in the absence of the CCS Cu chaperone. Proc. Natl. Acad. Sci. USA 2004, 101, 5964-5969. [CrossRef]

81. Raffa, N.; Osherov, N.; Keller, N.P. Copper Utilization, Regulation, and Acquisition by Aspergillus fumigatus. Int. J. Mol. Sci. 2019, 20, 1980. [CrossRef]

82. Solioz, M. Copper Disposition in Bacteria; Elsevier BV: Amsterdam, The Netherlands, 2019; pp. 101-113.

83. Outten, F.W.; Outten, C.E.; Hale, J.; O'Halloran, T.V. Transcriptional Activation of anEscherichia coliCopper Efflux Regulon by the Chromosomal MerR Homologue, CueR. J. Biol. Chem. 2000, 275, 31024-31029. [CrossRef]

84. Djoko, K.Y.; Xiao, Z.; Wedd, A.G. Copper Resistance in E. coli: The Multicopper Oxidase PcoA Catalyzes Oxidation of Copper(I) in CuICuII-PcoC. ChemBioChem 2008, 9, 1579-1582. [CrossRef]

85. Rademacher, C.; Masepohl, B. Copper-responsive gene regulation in bacteria. Microbiology 2012, 158, 2451-2464. [CrossRef]

86. Berg, J.; Tom-Petersen, A.; Nybroe, O. Copper amendment of agricultural soil selects for bacterial antibiotic resistance in the field. Lett. Appl. Microbiol. 2005, 40, 146-151. [CrossRef]

87. Borruso, L.; Harms, K.; Johnsen, P.J.; Nielsen, K.M.; Brusetti, L. Distribution of class 1 integrons in a highly impacted catchment. Sci. Total Environ. 2016, 566-567, 1588-1594. [CrossRef]

88. Hao, X.; Luthje, F.L.; Qin, Y.; McDevitt, S.F.; Lutay, N.; Hobman, J.L.; Asiani, K.; Soncini, F.C.; German, N.; Zhang, S.; et al. Survival in amoeba- a major selection pressure on the presence of bacterial copper and zinc resistance determinants? Identification of a "copper pathogenicity island". Appl. Microbiol. Biotechnol. 2015, 99, 5817-5824.

89. Shan, Y.; Tysklind, M.; Hao, F.; Ouyang, W.; Chen, S.; Lin, C. Identification of sources of heavy metals in agricultural soils using multivariate analysis and GIS. J. Soils Sediments 2013, 13, 720-729. [CrossRef]

90. Zhang, S.; Abbas, M.; Rehman, M.U.; Huang, Y.; Zhou, R.; Gong, S.; Yang, H.; Chen, S.; Wang, M.; Cheng, A. Dissemination of antibiotic resistance genes (ARGs) via integrons in Escherichia coli: A risk to human health. Environ. Pollut. 2020, 266, 115260. [CrossRef]

91. Baker-Austin, C.; Wright, M.S.; Stepanauskas, R.; McArthur, J. Co-selection of antibiotic and metal resistance. Trends Microbiol. 2006, 14, 176-182. [CrossRef]

92. Hu, H.H.; Wang, J.; Li, J.; Li, J.-J.; Ma, Y.-B.; Chen, D.; He, J. Field-based evidence for copper contamination induced changes of antibiotic resistance in agricultural soils. Environ. Microbiol. 2016, 18, 3896-3909. [CrossRef]

93. Tomasi, N.; Kretzschmar, T.; Espen, L.; Weisskopf, L.; Fuglsang, A.T.; Palmgren, M.G.; Neumann, G.; Varanini, Z.; Pinton, R.; Martinoia, E.; et al. Plasma membrane H+-ATPase-dependent citrate exudation from cluster roots of phosphate-deficient white lupin. Plant Cell Environ. 2009, 32, 465-475. [CrossRef]

94. Tomasi, N.; Mimmo, T.; Terzano, R.; Alfeld, M.; Janssens, K.; Zanin, L.; Pinton, R.; Varanini, Z.; Cesco, S. Nutrient accumulation in leaves of Fe-deficient cucumber plants treated with natural Fe complexes. Biol. Fertil. Soils 2014, 50, 973-982. [CrossRef]

95. Bravin, M.N.; Martí, A.L.; Clairotte, M.; Hinsinger, P. Rhizosphere alkalisation—a major driver of copper bioavailability over a broad $\mathrm{pH}$ range in an acidic, copper-contaminated soil. Plant Soil 2009, 318, 257-268. [CrossRef]

96. Faget, M.; Blossfeld, S.; Von Gillhaussen, P.; Schurr, U.; Temperton, V.M. Disentangling who is who during rhizosphere acidification in root interactions: Combining fluorescence with optode techniques. Front. Plant Sci. 2013, 4, 1-9. [CrossRef]

97. Leitenmaier, B.; Kupper, H. Compartmentation and complexation of metals in hyperaccumulator plants. Front. Plant Sci. 2013, 4, 374. [CrossRef]

98. Dell'Orto, M.; Santi, S.; Cesco, S.; Varanini, Z.; Zocchi, G.; De Nisi, P.; Pinton, R. Development of Fe?deficiency responses in cucumber ( Cucumis sativus L.) roots: Involvement of plasma membrane H + ?ATPase activity. J. Exp. Bot. 2000, 51, 695-701. [CrossRef]

99. Earmijo, G.; Eschlechter, R.; Eagurto, M.; Emuñoz, D.; Enúñez, C.; Arce-Johnson, P. Grapevine Pathogenic Microorganisms: Understanding Infection Strategies and Host Response Scenarios. Front. Plant Sci. 2016, 7, 382. [CrossRef]

100. Zendler, D.; Schneider, P.; Töpfer, R.; Zyprian, E. Fine mapping of Ren3 reveals two loci mediating hypersensitive response against Erysiphe necator in grapevine. Euphytica 2017, 213, 1-23. [CrossRef] 
101. Gessler, C.; Pertot, I.; Perazzolli, M. Plasmopara viticola: A review of knowledge on downy mildew of grapevine and effective disease management. Phytopathol. Mediterr. 2011, 50, 3-44. [CrossRef]

102. Zini, E.; Dolzani, C.; Stefanini, M.; Gratl, V.; Bettinelli, P.; Nicolini, D.; Betta, G.; Dorigatti, C.; Velasco, R.; Letschka, T.; et al. R-Loci Arrangement Versus Downy and Powdery Mildew Resistance Level: A Vitis Hybrid Survey. Int. J. Mol. Sci. 2019, $20,3526$. [CrossRef]

103. Di Gaspero, G.; Foria, S. Molecular Grapevine Breeding Techniques; Elsevier BV: Amsterdam, The Netherlands, 2015 ; pp. $23-37$.

104. Bove, F.; Rossi, V. Components of partial resistance to Plasmopara viticola enable complete phenotypic characterization of grapevine varieties. Sci. Rep. 2020, 10,1-12. [CrossRef]

105. Qiu, W.; Feechan, A.; Dry, I.B. Current understanding of grapevine defense mechanisms against the biotrophic fungus (Erysiphe necator), the causal agent of powdery mildew disease. Hortic. Res. 2015, 2, 15020. [CrossRef]

106. Giacomelli, L.; Zeilmaker, T.; Malnoy, M.; Van Der Voort, J.R.; Moser, C. Generation of mildew-resistant grapevine clones via genome editing. Acta Hortic. 2019, 1248, 195-200. [CrossRef]

107. Dalla Costa, L.; Malnoy, M.; Lecourieux, D.; Deluc, L.; Lecourieux, F.O.-; Thomas, M.R.; Torregrosa, L. The state-of-the-art of grapevine biotechnology and new breeding technologies (NBTS). OENO One 2019, 53, 189-212. [CrossRef]

108. Feechan, A.; Jermakow, A.M.; Torregrosa, L.; Panstruga, R.; Dry, I.B. Identification of grapevine MLO gene candidates involved in susceptibility to powdery mildew. Funct. Plant Biol. 2008, 35, 1255-1266. [CrossRef]

109. Winterhagen, P.; Howard, S.F.; Qiu, W.; Kovács, L.G. Transcriptional Up-Regulation of Grapevine MLO Genes in Response to Powdery Mildew Infection. Am. J. Enol. Vitic. 2008, 59, 159-168.

110. Pirrello, C.; Zeilmaker, T.; Bianco, L.; Giacomelli, L.; Moser, C.; Vezzulli, S. Mining downy mildew susceptibility genes: A diversity study in grapevine. bioRxiv 2020. [CrossRef]

111. Cesco, S.; Tolotti, A.; Nadalini, S.; Rizzi, S.; Valentinuzzi, F.; Mimmo, T.; Porfido, C.; Allegretta, I.; Giovannini, O.; Perazzolli, M.; et al. Plasmopara viticola infection affects mineral elements allocation and distribution in Vitis vinifera leaves. Sci. Rep. 2020, 10, 1-18. [CrossRef]

112. Chitarrini, G.; Riccadonna, S.; Zulini, L.; Vecchione, A.; Stefanini, M.; Larger, S.; Pindo, M.; Cestaro, A.; Franceschi, P.; Magris, G.; et al. Two-omics data revealed commonalities and differences between Rpv12- and Rpv3-mediated resistance in grapevine. Sci. Rep. 2020, 10, 1-15. [CrossRef]

113. Malacarne, G.; Vrhovsek, U.; Zulini, L.; Cestaro, A.; Stefanini, M.; Mattivi, F.; Delledonne, M.; Velasco, R.; Moser, C. Resistance to Plasmopara viticola in a grapevine segregating population is associated with stilbenoid accumulation and with specific host transcriptional responses. BMC Plant Biol. 2011, 11, 114. [CrossRef]

114. Badalucco, L.; Nannipieri, P. Nutrient transformations in the rhizosphere. In The Rhizosphere Biochemistry and Organic Substances at the Soil-plant Interface; CRC Press: Boca Raton, FL, USA, 2007; Volume 11, pp. 111-133.

115. Terrazas, R.A.; Giles, C.; Paterson, E.; Robertson-Albertyn, S.; Cesco, S.; Mimmo, T.; Pii, Y.; Bulgarelli, D. Plant-Microbiota Interactions as a Driver of the Mineral Turnover in the Rhizosphere. Adv. Clin. Chem. 2016, 95, 1-67. [CrossRef]

116. Pii, Y.; Borruso, L.; Brusetti, L.; Crecchio, C.; Cesco, S.; Mimmo, T. The interaction between iron nutrition, plant species and soil type shapes the rhizosphere microbiome. Plant Physiol. Biochem. 2016, 99, 39-48. [CrossRef]

117. Mimmo, T.; Pii, Y.; Valentinuzzi, F.; Astolfi, S.; Lehto, N.; Robinson, B.; Brunetto, G.; Terzano, R.; Cesco, S. Nutrient availability in the rhizosphere: A review. Acta Hortic. 2018, 1217, 13-28. [CrossRef]

118. Bayer, P.E.; Edwards, D. Machine learning in agriculture: From silos to marketplaces. Plant Biotechnol. J. 2020. [CrossRef]

119. Mulla, D.J. Spatial Variability in Precision Agriculture. In Encyclopedia of GIS; Springer Science and Business Media LLC: Berlin/Heidelberg, Germany, 2016; pp. 1-8.

120. Matese, A.; Di Gennaro, S.F. Technology in precision viticulture: A state of the art review. Int. J. Wine Res. 2015, 7, 69-81. [CrossRef]

121. Landonio, S.; (ARVAtec srl, Rescaldina, Italy). Personal Communication, 2020.

122. Maheswari, R.; Ashok, K.R.; Prahadeeswaran, M. Precision farming technology, adoption decisions and produc-tivity of vegetables in resource-poor environments. Agric. Econ. Res. Rev. 2008, 21, 415-424.

123. McBride, W.D.; Daberkow, S.G. Information and the adoption of precision farming technologies. J. Agri-Bus. 2003, $21,21-38$.

124. Kutter, T.; Tiemann, S.; Siebert, R.; Fountas, S. The role of communication and co-operation in the adoption of precision farming. Precis. Agric. 2011, 12, 2-17. [CrossRef]

125. Vecchio, Y.; Agnusdei, G.P.; Miglietta, P.P.; Capitanio, F. Adoption of Precision Farming Tools: The Case of Italian Farmers. Int. J. Environ. Res. Public Health 2020, 17, 869. [CrossRef]

126. Rodríguez-Molano, J.I.; Triana-Casallas, J.A.; Contreras-Bravo, L.E. Modeling and Simulation of Integration of Internet of Things and Manufacturing Industry 4.0. Programmieren für Ingenieure und Naturwissenschaftler 2018, 916, 231-241. [CrossRef]

127. Shamim, S.; Cang, S.; Yu, H.; Li, Y. Management approaches for Industry 4.0: A human resource management perspective. In Proceedings of the 2016 IEEE Congress on Evolutionary Computation (CEC), Vancouver, BC, Canada, 24-29 July 2016; pp. 5309-5316.

128. Wan, J.; Cai, H.; Zhou, K. Industrie 4.0: Enabling technologies. In Proceedings of the 2015 International Conference on Intelligent Computing and Internet of Things, Harbin, China, 17-18 January 2015; pp. 135-140.

129. Mazzetto, F.; Gallo, R.; Riedl, M.; Sacco, P. Proposal of an ontological approach to design and analyse farm information systems to support Precision Agriculture techniques. IOP Conf. Ser. Earth Environ. Sci. 2019, 275, 012008. [CrossRef] 
130. Balafoutis, A.T.; Koundouras, S.; Anastasiou, E.; Fountas, S.; Arvanitis, K. Life Cycle Assessment of Two Vineyards after the Application of Precision Viticulture Techniques: A Case Study. Sustainability 2017, 9, 1997. [CrossRef]

131. Brunori, E.; Maesano, M.; Moresi, F.V.; Scarascia Mugnozza, G.; Biasi, R. Towards sustainable viticulture: Key role of vineyard's precision monitoring. In Proceedings of the International Symposium on Technologies for Smart City, Malaga, Spain, 11-12 November 2019; p. 6.

132. Kuflik, T.; Prodorutti, D.; Frizzi, A.; Gafni, Y.; Simon, S.; Pertot, I. Optimization of copper treatments in organic viticulture by using a web-based decision support system. Comput. Electron. Agric. 2009, 68, 36-43. [CrossRef]

133. Román, C.; Llorens, J.; Uribeetxebarria, A.; Sanz, R.; Planas, S.; Arnó, J. Spatially variable pesticide application in vineyards: Part II, field comparison of uniform and map-based variable dose treatments. Biosyst. Eng. 2020, 195, 42-53. [CrossRef]

134. Lindblom, J.; Lundström, C.; Ljung, M.; Jonsson, A. Promoting sustainable intensification in precision agriculture: Review of decision support systems development and strategies. Precis. Agric. 2017, 18, 309-331. [CrossRef]

135. Santesteban, L. Precision viticulture and advanced analytics. A short review. Food Chem. 2019, 279, 58-62. [CrossRef]

136. Zarco-Tejada, P.J.; Hubbard, N.; Loudjani, P. Precision Agriculture: An Opportunity for eu Farmers-Potential Support with the Cap 2014-2020; Joint Research Centre (JRC) of the European Commission: Ispra, Italy, 2014.

137. Mazzetto, F.; Calcante, A.; Mena, A.; Vercesi, A. Integration of optical and analogue sensors for monitoring canopy health and vigour in precision viticulture. Precis. Agric. 2010, 11, 636-649. [CrossRef]

138. Vidoni, R.; Gallo, R.; Ristorto, G.; Carabin, G.; Mazzetto, F.; Scalera, L.; Gasparetto, A. ByeLab: An agricultural mobile robot prototype for proximal sensing and precision farming. In Proceedings of the ASME International Mechanical Engineering Congress and Exposition, Tampa, FL, USA, 3-9 November 2017.

139. Mazzetto, F.; Gallo, R.; Importuni, P.; Petrera, S.; Sacco, P. Automatic filling of field activities register, from challenge into reality. Chem. Eng. Trans. 2017, 58, 667-672. [CrossRef]

140. Lee, S.-G.; Yang, A.; Jeon, B.-H.; Park, H.-D. A structure of scalable and configurable interface for sensor and actuator devices in smart farming system. Int. J. Inn. Tech. Exp. Eng. 2019, 8, 2779-2786.

141. Pérez-Expósito, J.P.; Fernández-Caramés, T.M.; Fraga-Lamas, P.; Castedo, L. VineSens: An Eco-Smart Decision-Support Viticulture System. Sensors 2017, 17, 465. [CrossRef]

142. Fuentes, S.; Tongson, E. Advances and requirements for machine learning and artificial intelligence applications in viticulture. Wine Vitic. J. 2018, 33, 3-47.

143. De Mauro, A.; Greco, M.; Grimaldi, M. A formal definition of Big Data based on its essential features. Libr. Rev. 2016, 65, 122-135. [CrossRef]

144. Delgado, J.A.; Short, N.M.; Roberts, D.P.; Vandenberg, B. Big Data Analysis for Sustainable Agriculture on a Geospatial Cloud Framework. Front. Sustain. Food Syst. 2019, 3. [CrossRef]

145. Lioutas, E.D.; Charatsari, C.; La Rocca, G.; De Rosa, M. Key questions on the use of big data in farming: An activity theory approach. NJAS Wagening. J. Life Sci. 2019, 90, 100297. [CrossRef]

146. Penn, C. Twelve innovations from Vinitech 2018. Aust. N. Z. Grapegrow. Winemak. 2019, 660, 56.

147. Siebers, M.H.; Edwards, E.J.; Jimenezberni, J.A.; Thomas, M.R.; Salim, M.; Walker, R. Fast Phenomics in Vineyards: Development of GRover, the Grapevine Rover, and LiDAR for Assessing Grapevine Traits in the Field. Sensors 2018, 18, 2924. [CrossRef]

148. Mendes, J.; Pinho, T.M.; Dos Santos, F.N.; Sousa, J.J.; Peres, E.; Cunha, J.B.; Cunha, M.; Morais, R. Smartphone Applications Targeting Precision Agriculture Practices-A Systematic Review. Agronomy 2020, 10, 855. [CrossRef]

149. Caffaro, F.; Cremasco, M.M.; Roccato, M.; Cavallo, E. Drivers of farmers' intention to adopt technological innovations in Italy: The role of information sources, perceived usefulness, and perceived ease of use. J. Rural. Stud. 2020, 76, 264-271. [CrossRef]

150. Tey, Y.S.; Brindal, M. Factors influencing the adoption of precision agricultural technologies: A review for policy implications. Precis. Agric. 2012, 13, 713-730. [CrossRef]

151. Bai, C.; Ciano, M.P.; Orzes, G.; Sarkis, J. Industry 4.0 technologies assessment: A sustainability perspective. Int. J. Prod. Econ. 2020, 229, 107776. [CrossRef]

152. Luo, Y.; Guo, W.; Ngo, H.H.; Nghiem, L.D.; Hai, F.I.; Zhang, J.; Liang, S.; Wang, X.C. A review on the occurrence of micropollutants in the aquatic environment and their fate and removal during wastewater treatment. Sci. Total Environ. 2014, 473-474, 619-641. [CrossRef] 